
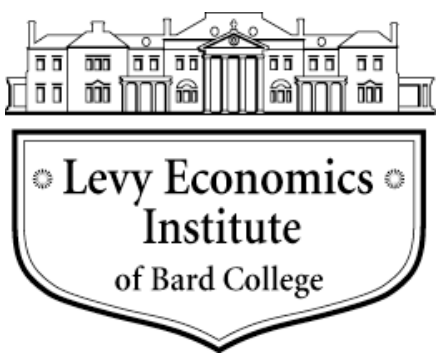

Working Paper No. 816

\title{
Coping with Imbalances in the Euro Area: Policy Alternatives Addressing Divergences and Disparities between Member Countries*
}

\author{
by
}

\author{
Eckhard Hein ${ }^{\dagger}$ \\ Levy Economics Institute of Bard College \\ Daniel Detzer \\ Berlin School of Economics and Law
}

September 2014

\footnotetext{
* The research leading to these results received funding from the European Union Seventh Framework Programme (FP7/2007-2013) under grant agreement $\mathrm{n}^{\circ} 266800$. A preliminary version of this paper was presented at the 11th International Conference Developments in Economic Theory and Policy in Bilbao, Spain, June 26-27, 2014. We are grateful to the participants, and in particular to Jerome Creel, for helpful comments, and to Jeffrey Althouse for editing the English style. Remaining errors are, of course, ours.

$\dagger$ Prof. Dr. Eckhard Hein, Berlin School of Economics and Law, Badensche Str. 50-51, 10825 Berlin, Germany, e-mail: eckhard.hein@hwr-berlin.de

$\ddagger$ Daniel Detzer, Berlin School of Economics and Law, Badensche Str. 50-51, 10825 Berlin, Germany, e-mail: daniel.detzer@hwr-berlin.de
}

The Levy Economics Institute Working Paper Collection presents research in progress by Levy Institute scholars and conference participants. The purpose of the series is to disseminate ideas to and elicit comments from academics and professionals.

Levy Economics Institute of Bard College, founded in 1986, is a nonprofit, nonpartisan, independently funded research organization devoted to public service. Through scholarship and economic research it generates viable, effective public policy responses to important economic problems that profoundly affect the quality of life in the United States and abroad.

Levy Economics Institute

P.O. Box 5000

Annandale-on-Hudson, NY 12504-5000

http://www.levyinstitute.org

Copyright (C) Levy Economics Institute 2014 All rights reserved 


\begin{abstract}
In this paper we outline alternative policy recommendations addressing the problems of differential inflation, divergence in competitiveness, and associated current account imbalances within the euro area. The major purpose of these alternative policy proposals is to generate sustainably high demand and output growth in the euro area as a whole, providing high levels of noninflationary employment, as well as preventing "export-led mercantilist" and "debt-led consumption boom" types of development, both within the euro area and with respect to the role of the euro area in the world economy. We provide a basic framework in order to systematically address the related issues, making use of Anthony Thirlwall's model of a "balance-of-paymentsconstrained growth rate." Based on this framework, we outline the required stance for alternative economic policies and then discuss the implications for alternative monetary, wage/incomes, and fiscal policies in the euro area as a whole, as well as the consequences for structural and regional policies in the euro-area periphery in particular.
\end{abstract}

Keywords: Competitiveness; Current Account Imbalances; Differential Inflation Rates; Euro Area Economic Policies

JEL Classifications: E61, E62, E63, E64 


\section{INTRODUCTION}

In this paper we outline alternative policy recommendations addressing the problems of differential inflation, divergence in competitiveness and associated current account imbalances within the euro area. The major purpose of these alternative policy proposals is to generate sustainably high demand and output growth in the euro area, providing high levels of noninflationary employment, as well as preventing "export-led mercantilist" and "debt-led consumption boom" types of development, both within the euro area and with respect to the role of the euro area in the world economy. These types of development, generated by "financedominated capitalism," have shaped the global and euro area economies before the crisis, and they have each proven to be unsustainable (Hein 2012, 2013, 2013/14; Hein and Dodig 2014). This paper builds on the analysis of the origins of intra-euro area imbalances and on the overview of the unsuccessful policy responses towards these imbalances in the companion papers by Carasco and Peinado (2014) and Dodig and Herr (2014a).

In order to motivate and structure our overview of policy alternatives, we start with Thirlwall's $(1979,2002)$ model of a "balance-of-payments-constrained growth rate" (BPCGR). This model allows the causes of current account imbalances and the role of inflation differentials and differential competitiveness to be systematically identified, and appropriate policy implications to be developed. We will build on initial attempts at applying this concept to the analysis of intra-euro area imbalances and drawing the economic policy implications in Hein (2012, Chapter 8) and Hein et al. (2012), and we will further refine and develop this kind of analysis here and compare the economic policy suggestions with those provided by other authors with similar objectives and intentions. In Section 2 we will start by presenting the theoretical framework, i.e., Thirlwall's BPCGR, and we will adjust it toward the conditions of a currency union, which will allow us to study the relationships between current account imbalances and price and non-price competitiveness in a consistent and systematic way. In Section 3 we will then outline the broad economic policy implications deriving from this framework which are meant to promote sustainable non-inflationary full-employment growth within the euro area, on the one hand, and to avoid unsustainable current account imbalances within the euro area but also with respect to the role of euro area as a whole in the world economy, on the other hand. Section 4 will then be devoted to a more precise discussion of an alternative coordinated macroeconomic policy mix for the euro area, which is understood as a 
policy package that would have to be jointly implemented. First, we will discuss the role of monetary policies and of the ECB, arguing that it should guarantee public debt of member countries and target low interest rates, in particular, as well as contribute to stabilizing the financial sector. Second, we will turn to wage and income policies and argue that their main target should be to stabilize nominal unit labor cost growth, and thus inflation rates, across the euro area, at some target rate, and contribute to constant and stable functional income distribution as a "by-product." Third, we will then outline the role of fiscal policies, which we believe shall stabilize the economy at non-inflationary, full-employment output levels with more or less balanced current accounts, in the short run and in the long run. For each of these policy areas we will first outline the general tasks of policy making within the broad economic policy mix; we will then specify these tasks and instruments for the conditions of the euro area. We will address the respective contributions to rebalancing the euro area, and we will finally touch on alternative suggestions by other authors. Against this background, we will then, in Section 5, turn to the discussion of some ideas to restructure the countries of the periphery, and the crisis countries, in particular, in order to facilitate medium- to long-run catching up with the more mature countries of the euro area core. Section 6 will briefly summarize and conclude.

\section{THEORETICAL FRAMEWORK}

In order to frame and structure our discussion of policy alternatives addressing divergence and disparities between euro area member countries regarding current account balances, and inflation and trends in competitiveness, we chose Thirlwall's (1979; 2002) model of a "balanceof-payments-constrained growth rate" (BPCGR) as a starting point. This model allows for a systematic and consistent discussion of the interrelationships between current account balances, inflation differentials and non-price competitiveness. Applying this model to a currency area yields the following determinants of the BPCGR for a single country, as shown in Appendix A: ${ }^{1}$

\footnotetext{
${ }^{1}$ McCombie (2002, p. 15) nicely summarizes the balance of payments constrained growth model as follow: "The central tenet of the balance-of-payments-constrained growth model is that a country cannot run a balance-ofpayments deficit for any length of time that has to be financed by short-term capital flows and which results in an increasing net foreign-debt-to-GDP ratio. If a country attempts to do this, the operation of the international financial markets will lead to increasing downward pressure on the currency, with the danger of a collapse in the exchange rate and the risk of a resulting depreciation/inflation spiral. There is also the possibility that the country's international credit rating will be downgraded. Consequently, in the long run, the basic balance (current account plus long-term capital flows) has to be in equilibrium. An implication of this approach is that there is nothing that
} 


$$
\hat{\mathrm{Y}}_{\mathrm{d}}^{\mathrm{b}}=\frac{(1+\eta+\psi)\left(\hat{\mathrm{p}}_{\mathrm{d}}-\hat{\mathrm{p}}_{\mathrm{f}}\right)+\varepsilon \hat{\mathrm{Y}}_{\mathrm{f}}}{\pi}, \quad \eta, \psi<0, \varepsilon, \pi>0
$$

where $\hat{Y}_{d}^{b}$ is the BPCGR for the domestic economy; $\hat{Y}_{f}$ is the foreign real GDP growth rate, i.e., the growth rate of the rest of the euro area, since its current account with the rest of the world was roughly balanced before the financial, economic and euro crises, and should remain in balance in the future; $\hat{\mathrm{p}}_{\mathrm{d}}$ is domestic inflation; $\hat{\mathrm{p}}_{\mathrm{f}}$ is foreign inflation, i.e., inflation in the rest of the euro area; $\eta$ is the price elasticity of the demand for exports; $\psi$ is the price elasticity of demand for imports; $\varepsilon$ is the income elasticity of the demand for exports; and $\pi$ is the income elasticity of the demand for imports. Disparities in $\varepsilon$ and $\pi$ among countries are considered to reflect differences in non-price competitiveness. With given foreign GDP growth and given foreign inflation, the BPCGR of a single economy can be improved by lower domestic inflation, provided that $1+\eta+\psi<0$ (i.e., the Marshall-Lerner condition holds), a higher income elasticity of domestic exports, or a lower income elasticity of domestic imports.

Applying the model to the member countries of the euro area means that each of the member countries should grow at its BPCGR (i.e., avoid current account surpluses and current account deficits), however, without taking the BPCGR as exogenously given, as will be explained below. In principle, each of the countries should also target the same rate of inflation and thus equalize domestic and foreign inflation. This is so because a rate of inflation below the foreign rate will mean a higher BPCGR of the country under consideration; it implies, however, a lower BPCGR of the other countries of the euro area, provided that its current account with the rest of the world is roughly balanced. Following the rule of equal inflation rates across the member countries of the currency union, therefore, implies that the BPCGR for each of the member countries would become:

$$
\hat{\mathrm{Y}}_{\mathrm{d}}^{\mathrm{b}}=\frac{\varepsilon \hat{\mathrm{Y}}_{\mathrm{f}}}{\pi}=\frac{\hat{\mathrm{X}}}{\pi} .
$$

Note that with balanced current accounts within the currency area, and with equal rates of inflation, GDP growth rates of member countries may nonetheless differ, depending on the relative income elasticities of demand for exports and imports. Also note that the improvement

guarantees that this rate will be the one consistent with the full employment of resources or the growth of productive potential." 
of the BPCGR of a single country within a currency area, by means of increasing the income elasticity of exports or by reducing the income elasticity of imports, has the adverse effect on the BPCGR of the rest of the currency area, because it will mean increasing its income elasticity of imports and decreasing the income elasticity for its exports - always assuming a roughly balanced current account of the currency area with the rest of the world.

Since, according to equation (1), Thirlwall's BPCGR, applied to a currency union (without any internal nominal exchange rates), is determined by inflation differentials, provided that the Marshall-Lerner condition can be assumed to hold, by the income elasticities of the demand for imports and exports, and by the rate of real GDP growth of the trading partners, we can identify several causes for current account imbalances in a currency union.

The first, and general one, is, of course, GDP growth differentials between the different euro area member countries exceeding those implied by their respective BPCGRs. These will be associated with a deterioration of the current account position in the countries growing "too fast," and an improvement in the countries growing "too slow." From an economic policy perspective, we can distinguish two different causes for countries growing "too fast" relative to their BPCGR - catch-up processes associated with high investment in productive capital, on the one hand, and bubble-induced growth associated with asset and/or housing price booms and high investment in real estate and/or high debt-financed consumption, on the other hand. Whereas the former should be welcomed from an economic policy perspective aiming at "promot(ing) economic, social and territorial cohesion, and solidarity among Member States" (Treaty on European Union, Article 3.3), the latter should be avoided by appropriate economic policies and institutions.

From another angle we could also argue that the BPCGRs are "too low" or "too high" given the actual growth rates of the respective economies. The first reason for this could be toohigh inflation differentials, which cause a "too-low" or "too-high" BPCGR for the respective countries, given their actual growth differentials. A major cause for inadequate inflation differentials is, of course, differentials in unit labour cost growth, but changes in mark-ups in firms' pricing, as well as differentials in the development of other input costs, must also to be taken into account. A second cause is related to quality competitiveness and hence income elasticities of exports and imports. For given growth differentials within a currency union, we will observe current account imbalances if income elasticities of demand for exports of rapidly growing catching-up countries are "too low" and income elasticities of demand for imports are 
"too high," thus reducing the BPCGR below the actual growth rate. Slowly growing mature economies will contribute to imbalances if the reverse holds true, that is "too-high" income elasticities of the demand for their exports and "too-low" income elasticities of their demand for imports, hence lifting the BPCGR above the actual growth rate.

\section{THE GENERAL STANCE REQUIRED FOR POLICY ALTERNATIVES}

From this perspective, economic policies would generally have to focus on generating high, non-inflationary, demand growth in the euro area, as close as possible to the euro area BPCGR, on the one hand, and to improve non-price competitiveness with respect to the rest of the world, in order to lift the euro area BPCGR, on the other hand. Furthermore, preventing "export-led mercantilist" and "debt-led consumption boom" types of development, which have dominated the euro area before the crisis, is of utmost importance, both within the euro area but also with respect to the role of the euro area as a whole in the world economy. In order to internally rebalance the euro area, economic policies would have to focus on the mutual adjustment of actual growth rates of member countries and the respective BPCGRs. In the short run, this means stimulating aggregate demand and growth in the current account surplus countries relative to the euro area average trend, and dampening aggregate demand and growth relative to the euro area average trend in the current account deficit countries. Lowering unit labor cost growth and inflation relative to the euro area average trend in current account deficit countries, avoiding deflation and demanding depressing effects of redistribution at the expense of the labor income share and low-income households, and increasing unit labor cost growth and inflation in current account surplus countries will contribute to this effort-lifting the respective BPCGRs for current account deficit countries and lowering them for current account surplus countries. Improving non-price competitiveness of current-account deficit countries relative to current account surplus countries will have the same effect via the respective income elasticities of demand for imports and exports. However, these are rather medium- to long-run economic policy targets, because they involve process and product innovations as well as structural changes in the respective economies.

Finally, even if the euro area were successful in developing and applying appropriate policies in line with these targets, we should not expect perfectly balanced current accounts of member countries, neither in the short run, nor in the long run, because of necessary catching-up 
processes, in particular. This will imply that the catching-up countries will have a tendency to grow above their BPCGRs, whereas the mature countries will tend to grow below their respective BPCGRs. For this reason, the euro area will have to develop a stable financing mechanism for the associated current account deficits of catching-up member countries. As we show in Appendix B, as long as the current account deficit country (the catching-up country in the euro area) is growing sustainably faster than the mature current account surplus country, there is no risk of exploding net foreign debt-GDP ratios in the current account deficit country. And provided that the growth rate of domestic demand in the current account deficit country exceeds the rate of interest on net foreign debt, the stabilization of the net foreign debt-GDP ratio is perfectly compatible with a trade deficit of the current account deficit country, as we also show in Appendix B.

If we include a constant and sustainable net inflow of long-term capital (C), the BPCGR from equation (1), as shown in Appendix A, turns to:

$$
\hat{\mathrm{Y}}_{\mathrm{d}}^{\mathrm{b}}=\frac{(1+\theta \eta+\psi)\left(\hat{\mathrm{p}}_{\mathrm{d}}-\hat{\mathrm{p}}_{\mathrm{f}}\right)+\theta \varepsilon \hat{\mathrm{Y}}_{\mathrm{f}}+(1-\theta)\left(\hat{\mathrm{C}}-\hat{\mathrm{p}}_{\mathrm{d}}\right)}{\pi},
$$

with $\theta$ as the share of export revenues in total receipts to pay for imports, $(1-\theta)$ as the share or net capital inflows, and $\hat{C}$ as the growth rate of net capital inflows, measured in domestic currency, required to finance persistent current account deficits. With equal rates of inflation across the currency area, this would become:

$$
\hat{\mathrm{Y}}_{\mathrm{d}}^{\mathrm{b}}=\frac{\theta \varepsilon \hat{\mathrm{Y}}_{\mathrm{f}}+(1-\theta)\left(\hat{\mathrm{C}}-\hat{\mathrm{p}}_{\mathrm{d}}\right)}{\pi}=\frac{\theta \hat{\mathrm{X}}+(1-\theta)\left(\hat{\mathrm{C}}-\hat{\mathrm{p}}_{\mathrm{d}}\right)}{\pi} .
$$

Comparing equation (4) with equation (2) shows that net capital inflows lift the BPCGR of the current account deficit country if the growth rate of these inflows in real terms, taking into account domestic inflation, exceeds the growth rate of exports, or the growth rate of foreign GDP multiplied by the income elasticity of exports.

\section{MORE CONCRETE POLICY PROPOSALS FOR THE EURO AREA}

It is obvious - and developed extensively in the companion paper by Dodig and Herr (2014a) that the current economic policy framework of the euro area is inappropriate to deal with the 
requirements outlined above. ${ }^{2}$ In fact, the current policy framework and the stance of the applied policies have even reinforced current account imbalances through different channels. First, they were unable to prevent significant inflation differentials to emerge within the euro area, mainly by undermining the conditions for effective wage bargaining conditions as a main tool for this. Second, they did not provide the appropriate tools for domestic demand management in order to adjust the actual rate of growth of each country toward the BPCGR, mainly through applying a “one-size-fits-all” policy with respect to government budget balances and government debt in the context of the Stability and Growth Pact (SGP). Third, they did not provide any effective policy tools to adjust the BPCGR of the high-growth current account deficit countries toward the respective growth rates, because of the lack of any consistent industrial and development strategy for the euro area as a whole and for the catching-up countries, in particular, making sure that capital inflows into these countries support long-run sustainable growth.

Therefore, alternative policy proposals would have to remedy these deficiencies, aiming at non-inflationary full-employment growth in the euro area as a whole, as well in as in each of its member countries, with sustainable current account deficits/surpluses in the member countries - and a roughly balanced current account for the euro area as a whole in order to contribute to balanced growth of the world economy. Preliminary outlines have been presented in Hein (2012, Chapter 8; 2013; 2013/14), Hein and Truger (2005, 2007, 2011) and Hein et al. (2012), among several others, based on general post-Keynesian macroeconomic models with the respective implications for the macroeconomic policy mix (Arestis 2013, Hein and Stockhammer 2010, 2011). We will build on these approaches.

Before we start, it should be pointed out that the suggestions for monetary, wage/incomes, fiscal and industrial/regional policies outlined below should be understood as a policy package, which would have to be implemented in a coordinated way. The main reason for this is that policy makers and their instruments do not affect just one target variable (employment, growth, inflation, external balance), but have effects on several targets, in the short and in the long run. Coordination means intra-coordination of national, as well as European institutions within the respective policy area and inter-coordination among these areas

\footnotetext{
${ }^{2}$ See also the contributions by Arestis (2011), Arestis and Sawyer (2011), De Grauwe (2011a, 2013), Hein and Truger (2005, 2011), Hein et al. (2012), among several others.
} 
of policy making at national and European levels, in particular. ${ }^{3}$ For this the macroeconomic dialogue and a completely revamped European semester, following and applying the policy mix to be outlined below could provide the institutional framework.

\subsection{Monetary Policy}

First, central banks' interest rate policies should abstain from attempting to fine tune unemployment in the short run and inflation in the long run, as suggested by New Consensus Macroeconomics (NCM). ${ }^{4}$ Varying interest rates have cost effects and distribution effects on the business sector, which may be effective in achieving inflation targets in the short run, in particular if the economy is facing accelerating inflation. With accelerating inflation, increasing the base rate of interest under the control of the central bank will finally also make credit and financial market rates increase, and will be able to choke off an investment boom. But if accelerating disinflation, and finally deflation, prevail, monetary interest rate policies will be ineffective: first, due to the zero lower bound of the nominal interest rate; second, due to rising mark-ups in the setting of interest rates in credit and financial markets by banks and financial intermediaries, due to increasing risk and uncertainty premia; and third, due to interest rate inelasticities of real investment of firms in a disinflationary or deflationary climate. Further on, in the long run, rising interest rates, applied successfully in order to stop accelerating inflation in the short run, will feed conflicting-claims inflation again, because price setting of surviving firms will have to cover higher interest costs.

Therefore, central banks, and hence the ECB, should focus on targeting low real interest rates in credit and financial markets, as it is included in the mandate for the US Federal Reserve (Meyer 2001), in order to avoid unfavorable cost and distribution effects on firms and workers, while favoring rentiers. ${ }^{5}$ A slightly positive long-term real rate of interest, below the long-run rate of productivity growth, seems to be a reasonable target. Rentiers' real financial wealth will be protected against inflation, but redistribution of income in favor of the productive sector and at the expense of the rentiers will take place, which should be favorable for real investment, employment, and growth. Furthermore, central banks have to act as a "lender of last resort" in

\footnotetext{
${ }^{3}$ See Hein and Truger (2005), as well as the contributions in Hein et al. (2005) for conceptual considerations in this respect.

${ }^{4}$ For the NCM see Clarida et al. (1999) and Goodfriend and King (1997), and for detailed critiques of the NCM, see Arestis (2009), Arestis/Sawyer (2004a), and Hein and Stockhammer (2010).

${ }^{5}$ See Rochon and Setterfield (2007) for a review of post-Keynesian suggestions regarding the "parking it" approach toward interest rate policies of central banks and the rate of interest central banks should target.
} 
periods of liquidity crisis, and central banks should be involved in the regulation and the supervision of financial markets. This includes the definition of credit standards for refinance operations with commercial banks, the implementation of compulsory reserve requirements for different types of assets to be held with the central bank, and even credit controls in order to channel credit into desirable areas and to avoid credit-financed bubbles in certain markets (De Grauwe 2011b; Detzer 2012; Palley 2004, 2010).

Most importantly, in the present situation, the ECB should not only act as a lender of last resort for the banking system, it should also guarantee public debt of the euro area member countries in a convincing and unconditional way, acting as a lender of last resort to the governments, too.

"National governments in a monetary union issue debt in a 'foreign' currency, i.e. one over which they have no control. As a result, they cannot guarantee to the bondholders that they will always have the necessary liquidity to pay out the bond at maturity. This contrasts with "stand alone" countries that issue sovereign bonds in their own currencies. This feature allows these countries to guarantee that the cash will always be available to pay out the bondholders. Thus in a stand-alone country there is an implicit guarantee that the central bank is a lender of last resort in the government bond market." (De Grauwe 2011b, p. 2)

The ECB, as a lender of last resort for member country governments, would allow member countries to issue debt in their "own currency," and it would immediately reduce the pressure imposed by financial markets on those countries presently in crisis, allowing these countries to regain fiscal sovereignty. ${ }^{6}$ It would thus provide the conditions for a long-run oriented solution to the current account imbalances within the euro area, as we will explain in the following sections.

In July 2012 the ECB took a major step in this direction when the President of the ECB, Mario Draghi (2012), announced that "(w)ithin our mandate, the ECB is ready to do whatever it takes to preserve the euro." However, this was specified later on, such that the ECB's willingness to intervene into secondary government bond markets, in the context of Outright Monetary Transactions (OMT), was made conditional on the respective country applying

\footnotetext{
${ }^{6}$ According to De Grauwe (2011a), a "bad equilibrium," characterized by high interest rates, recessionary forces, increasing budgetary problems and increasing probability of insolvency, would be prevented.
} 
EFSF/ESM macroeconomic adjustment programs (ECB 2012). ${ }^{7}$ This link is detrimental to recovery in the crisis country and to rebalancing the euro area at high levels of economic activity, because imposing fiscal austerity policies on the countries in question will make the downswing worse (as it did in 2012 and 2013), lead to the (threat of) deflationary stagnation and will not bring government debt-GDP ratios down (as has been observed in the course of the euro crisis) (De Grauwe 2011a; Hein 2013, 2014). ${ }^{8}$

Therefore, Hein $(2013,2014)$ has argued that the ECB could simply announce that it will intervene unconditionally in secondary government bond markets as soon as the nominal rate of interest on government bonds (i) exceeds the long-run nominal rate of growth of the respective country $j$-i.e., the sum of real GDP growth $\left(\hat{Y}_{j}\right)$ plus the rate of inflation $\left(\hat{p}_{j}\right)$ :

$$
i_{j} \leq \hat{p}_{j}+\hat{Y}_{j}
$$

This would imply country-specific caps on nominal interest rates on government bonds (and to the extent that government bond yields are a benchmark also for long-term interest rates in the respective countries in general), making sure that long-term real interest rates do not exceed real GDP growth trends. If government deficits or debt were inflationary - which would have to be prevented by fiscal policies, as will be addressed further below-governments would be automatically punished by the ECB, tolerating a higher nominal long-term interest rate, according to this rule. This is not, and should not be, an inflation targeting strategy. De Grauwe (2011b) has suggested a similar rule, arguing that the ECB should commit itself to providing unlimited liquidity as soon as the government bond rate of a specific country exceeds the riskfree rate — which is considered to be the rate on German government bonds-by 200 basis

\footnotetext{
7 “A necessary condition for Outright Monetary Transactions is strict and effective conditionality attached to an appropriate European Financial Stability Facility/European Stability Mechanism (EFSF/ESM) programme. Such programmes can take the form of a full EFSF/ESM macroeconomic adjustment programme or a precautionary programme (Enhanced Conditions Credit Line), provided that they include the possibility of EFSF/ESM primary market purchases. The involvement of the IMF shall also be sought for the design of the country-specific conditionality and the monitoring of such a programme." (ECB 2012)

${ }^{8}$ According to the May 2014 update of the European Commission (2014) AMECO database, from the 12 initial and core Euro area member countries, in the forecast for 2014 only Germany, Austria, Belgium and France will have recovered and exceeded their respective 2007 real GDP levels, whereas Greece, Ireland, Spain, Italy, Portugal, the Netherlands and Finland, as well as the EU12 as a whole will still remain well below their 2007 levels. In 2014 Greece will suffer from deflation, and Ireland, Spain, Portugal, Italy, the Netherlands and Belgium will be facing severe deflationary risks, with inflation rates (well) below one percent. Government debt-GDP ratios for 2014 are projected to decline only in Germany, Ireland, and Portugal, whereas the other countries will have to face further rising ratios.
} 
points, in order to prevent moral hazard. However, this seems to be more arbitrary and less focused than the suggestion by Hein $(2013,2014)$.

The suggestions outlined here are different from those proposals for "eurobonds" of different types, which are focusing on joint guarantees for only parts of government debt of member countries (Brunnermeier et al. 2011; De Grauwe and Moesen 2009; Delpla and von Weizsäcker 2010; European Commission 2011; Palley 2011). ${ }^{9}$ Although these suggestions can be considered to be steps in the right direction, they still include major parts of government debt of member countries that are not backed by the ECB, and hence remain susceptible to financial market speculation. Even worse are suggestions for eurobonds that are combined with fixed rules for government debt repayment (SVR 2011), because they do not acknowledge the macroeconomic role of government deficits and debt, as we will outline below.

\subsection{Wage and Incomes Policy}

In an alternative macroeconomic policy mix, incomes and wage policies should take responsibility for nominal stabilization in particular, that is, for stable inflation rates. In the end, accelerating inflation is always the result of unresolved distribution conflicts. If distribution claims of firms, rentiers, government, and the external sector are constant, nominal wages should therefore rise according to the sum of long-run economy-wide growth of labor productivity plus the inflation target. A reduction of claims of the other actors, however, would allow for an increase of nominal wages exceeding this benchmark. Applying this norm to the euro area means that nominal wages should rise according to the sum of long-run average growth of labor productivity in the national economy plus the target rate of inflation for the euro area as a whole:

$$
\hat{w}_{j}=\hat{y}_{j}+p^{T}
$$

with $\hat{w}, \hat{y}$ and $p^{T}$ denoting nominal wage growth and labor productivity growth in country $\mathrm{j}$ and the inflation target for the euro area as a whole. Following such a wage norm would contribute to equal inflation rates across the euro area, assuming mark-ups and unit non-wage costs in pricing to be roughly constant. It would prevent the improvement of the BPCGR of a single country at the expense of the rest of the euro area and it would thus prevent mercantilist strategies based on nominal wage moderation in general.

\footnotetext{
${ }^{9}$ See Bibow (2013) for a short overview and assessment.
} 
In order to contribute to the rebalancing of the current accounts within the euro area at high levels of economic activity by means of re-adjusting relative price competitiveness, wage policies for an intermediate period of time would have to deviate from the norm outlined above. Nominal wage growth in current account surplus countries would have to exceed the norm, whereas nominal wage growth in the current account deficit countries would have to fall short of this norm. Stockhammer and Onaran (2012) have suggested a simple macroeconomic wage rule for the EU, which we adapt for the euro area:

$$
\hat{w}_{j}=\hat{y}_{j}+p^{T}+\alpha\left(U_{L C} C_{E A}-U_{j}\right),
$$

where ULC denotes nominal unit labor costs in the euro area (EA) and in country j. The inflation target would have to be set such as to avoid deflation in all countries, which means it would have to be raised above the current level of "below, but close to two per cent."

To achieve the nominal wage growth targets, a high degree of wage bargaining coordination at the macroeconomic level, and organized labor markets with strong labor unions and employer associations seem to be necessary conditions. ${ }^{10}$ Government involvement in wage bargaining may be required, too. In particular, minimum wage legislation, especially in countries with highly deregulated labor markets and increasing dispersion of wages, will be helpful for nominal stabilization at the macroeconomic level, apart from its usefulness in terms of containing wage inequality. Furthermore, legal extensions of wage bargaining result throughout the whole industry or sector and other extension mechanisms, as well as public sector bargaining, setting the pattern for private sectors, which could be helpful.

For the euro area and the European Union this implies that the prevalent and dominating orientation of labor market and social policies toward deregulation and flexibilization of labor markets, nominal and real wage restraint and falling wage shares - as previously enshrined in the Employment Guidelines, the Broad Economic Policy Guidelines and now in the Country Specific Recommendations of the European Semester and the Memoranda of Understanding with the crisis countries ${ }^{11}$ — will have to be abandoned in favor of reorganizing labor markets, stabilizing labor unions and employer associations, legal extensions of collective wage bargaining results, euro area-wide minimum wage legislation, and so on. This could provide the

${ }^{10}$ See Hein (2002) and Schulten (2002) for reviews of the related macroeconomic and industrial relations theoretical and empirical literature.

${ }^{11}$ See ETUI (2014, Chapters 2-5) and Schulten and Müller (2013) for accounts of the most recent developments of wage bargaining, employment and inequality in the EU. 
institutional requirements for the effective implementation of wage policies stabilizing inflation at the target rate as well as stabilizing functional income shares, ceteris paribus. On the one hand, this would imply supporting and encouraging attempts of European trade unions (and employer associations) at cross-border coordination of wage bargaining along these lines. ${ }^{12} \mathrm{On}$ the other hand, this could be supported by coordinated minimum wage policies in the EU and in the euro area. The European Trade Union Confederation (ETUC 2012) had recommended setting the minimum wage at a level of at least 50 percent of the average wage or 60 percent of the median wage in the respective member countries. ${ }^{13}$ Following this idea, the OFCE/IMK/ECLM (2013, Chapter 3) suggest that statutory minimum wages should be introduced in those countries where they do not exist, unless collective wage-setting institutions are strong and coverage is high (as in Austria, for example). These minimum wages should then be adjusted to reflect productivity growth and the current account balance-assuming that the latter is relevantly affected by price competitiveness. In order to contribute to internally rebalancing the euro area, it is suggested that only countries with roughly balanced current accounts raise the minimum wage according to the inflation target (which is assumed to remain at 2 percent). Current account deficit countries, however, should only raise it by 1 percent, and current account surplus countries by 3 percent. However, we would argue that such an approach only makes sense if the long-run productivity growth trend in each country is included, as this would ensure that relative nominal unit labor cost growth contributes to rebalancing price competitiveness.

Although wage bargaining coordination along the lines outlined above will have some merits in terms of reducing inequality within member countries, preventing further downward pressures on labor income shares exerted by competitive wage policies and beggar-thy-neighbor strategies, and harmonizing inflation rates across the euro area, we would not expect too much in terms of rebalancing the current accounts within the euro area. Applying vector autoregression analyses on quarterly data for euro area member countries (1975-2005), Arghyrou and Chortareas (2008, p. 752) find that "relative incomes have been playing a more prominent role than real exchange rates in long-run current account determination. This implies that the current account deterioration observed in countries such as Greece and Spain following

${ }^{12}$ See Schulten (2005) for a pre-crisis review of the attempts of European trade unions at coordinating wage bargaining aiming at real wage growth in line with national trend labour productivity growth and at preventing beggar-thy-neighbour policies based on wage dumping.

${ }^{13}$ See also Schulten (2012) for an elaboration on European minimum wage policy. 
the introduction of the euro is mainly due to higher than average growth rates." This finding is well in line with a conclusion drawn by the European Commission (2010, p. 10), which argues with regard to euro area member countries that "[a] large part of the cross-country divergence in the current account since the late 1990s is rooted in domestic demand factors. [...] Stronger relative demand pressures in a given Member State tend to fuel import demand and depress the current account. [...] Differences in export performance-and therefore price competitivenessalso contributed to the divergence of current accounts but, in most Member States, this was of second order compared with domestic demand factors." Carasco and Peinado (2014) in their panel estimations for the euro area member countries (1995-2012) find some effects of real GDP growth differentials relative to average euro area growth-indicating catching-up factors - and of nominal unit labor cost growth differentials, indicating divergent price competitiveness, on the current account balance, which become, however, smaller if only the pre-crisis period (1999 - 2010) is considered. Furthermore, they find a considerable structural component in their estimations, which is considered to represent the effects of the industrial structure and the non-price competitiveness of a country on its current account. And for Germany, as the main current account surplus country, Schröder (2011) and Storm and Naastepad (2014) have only found small effects of price competitiveness on the German trade balance. The development of the German trade balance is almost completely explained by foreign demand relative to domestic demand dynamics, in their estimations. Interestingly, these findings seem to be broadly in line with those by Kollmann et al. (2014) based on an estimated Dynamic Stochastic General Equilibrium (DSGE) model with three "countries": Germany, the rest of the euro area and the rest of the world $\left(1995\right.$ - 2013). ${ }^{14}$ All of this evidence seems to be well in line with Thirlwall's (2002, p. 78) conclusion that "(t)he only sure and long-term solution to raising a country's growth rate consistent with balance of payments equilibrium on current account is structural change to raise $\varepsilon$ [the income elasticity of the demand for exports] and to reduce $\pi$ [the income elasticity of the demand for imports]." This seems to also be true

\footnotetext{
14 "Our findings are consistent with the view that adverse shocks to domestic demand were key drivers of the surplus, especially after the mid-2000s. Our analysis also supports the official German view that strong external demand and German competitiveness gains (wage moderation and technological improvements) were important sources of the German external surplus. However, strong external demand and German competitiveness gains explain, at most $1 / 3$ to $1 / 2$ of the surplus; strong external demand mattered mainly before the financial crisis, while wage restraint induced by labour market reforms contributed to the German surplus after the mid-2000s. The relative role of these factors has thus varied greatly across time. Positive shocks to the German saving rate have been especially important since the mid-2000s." (Kollmann et al. 2014, p. 4)
} 
for countries within a currency union, in which nominal exchange rate adjustments to counter divergences in inflation rates are no longer available.

Furthermore, if we do not only focus on the link between wage bargaining, nominal unit labor cost growth, inflation and price competitiveness, but take into account that applying the nominal wage growth rule in equation (7) might have effects on functional income distribution, too- contributing to rebalancing current accounts - we have to acknowledge that these effects are small. Applying standard estimations for the propensities to save from wages and from profits from the respective econometric literature, Hein and Truger (2014a, 2014b) have recently shown that the labor income share in Germany would have to rise to levels not seen in post-World War II German history, in order to boost private consumption and to allow for both 1) a nearly balanced government budget, respecting the newly introduced German Debt Brake, and 2) a balanced current account at given high levels of aggregate demand, output and employment.

All of this implies that the major burden for internally rebalancing the euro area should fall on fiscal policies, adjusting the actual growth rate towards the BPCGR in the short run, and on structural and regional policies, raising the BPCGR in the periphery in the medium to long run.

\subsection{Fiscal Policy}

In a coordinated policy mix, fiscal policies should take over responsibility for real stabilization, full employment, and also a more equal distribution of disposable income. This has several aspects. By definition the excess of private saving $(\mathrm{S})$ over private nominal investment $\left(\mathrm{p}_{\mathrm{d}} \mathrm{I}\right)$ at a given level of economic activity and employment has to be absorbed by the excess of nominal exports $\left(\mathrm{p}_{\mathrm{d}} \mathrm{X}\right)$ over nominal imports $\left(\mathrm{p}_{\mathrm{f}} \mathrm{eM}\right)$ (including the balance of primary income and the balance of income transfers, thus the current account balance), plus the excess of government spending $(\mathrm{G})$ over tax revenues $(\mathrm{T})$ :

$$
\mathrm{S}-\mathrm{p}_{\mathrm{d}} \mathrm{I}=\mathrm{p}_{\mathrm{d}} \mathrm{X}-\mathrm{p}_{\mathrm{f}} \mathrm{eM}+\mathrm{G}-\mathrm{T} .
$$

Therefore, with balanced current accounts $\left(\mathrm{p}_{\mathrm{d}} \mathrm{X}-\mathrm{p}_{\mathrm{f}} \mathrm{eM}=0\right)$, government deficits in the longrun perspective (D) have to permanently take up the excess of private saving over private investment in order to ensure a desired high level of employment: 


$$
\mathrm{D}=\mathrm{G}-\mathrm{T}=\mathrm{S}-\mathrm{p}_{\mathrm{d}} \mathrm{I} \cdot{ }^{15}
$$

As is well known from Domar (1944), and shown in Appendix C, a constant government deficit-GDP ratio $\left(\mathrm{D} / \mathrm{Y}^{\mathrm{n}}\right)$ with a constant long-run nominal GDP growth rate $\left(\hat{\mathrm{Y}}^{\mathrm{n}}\right)$ will make the government debt-GDP ratio $\left(\mathrm{B} / \mathrm{Y}^{\mathrm{n}}\right)$ converge toward a definite value in the long run:

$$
\frac{B}{Y^{n}}=\frac{\frac{D}{Y^{n}}}{\hat{Y}^{n}} .
$$

Therefore, there will be no problem of accelerating public debt-GDP ratios. Furthermore, as shown in Appendix C, nominal interest rates falling short of nominal GDP growth and hence tax revenue growth (or low real interest rates falling short of real GDP growth) will prevent government debt services from redistributing income in favor of rentiers, which would be detrimental to aggregate demand and growth. ${ }^{16}$ That is why targeting low interest rates on government bonds by the central bank is so important for our policy package.

Permanent government deficits should be directed toward public investment in a wider sense (including increasing public employment), providing the economy with public infrastructure, and public education at all levels (kindergartens, schools, high schools, universities) in order to promote structural change toward an environmentally sustainable longrun growth path. Apart from this permanent role of government debt, which also supplies a safe haven for private saving and thus stabilizes financial markets, counter-cyclical fiscal policiestogether with automatic stabilizers - should stabilize the economy in the face of aggregate demand shocks. From these considerations we get the following requirements for fiscal policies:

$$
\mathrm{D}=\mathrm{D}_{\mathrm{L}}+\mathrm{D}_{\mathrm{S}}\left(\mathrm{Y}^{\mathrm{T}}-\mathrm{Y}\right), \quad \mathrm{D}_{\mathrm{S}}>0,
$$

with $D_{L}$ as permanent government deficit (or surplus), which is required to keep output at noninflationary full employment target $\left(\mathrm{Y}^{\mathrm{T}}\right)$ in the long run; the government deficit (surplus) balancing the private sector surplus (deficit) with a roughly balanced current account; and $\mathrm{D}_{\mathrm{S}}$ as the reaction in the case of short-run deviations of output from target. It has to be added that the non-inflationary full employment level of output itself is not independent of government expenditures, nor of government investment in a broader sense in particular, because of labor

${ }^{15}$ This is, of course, the "functional finance" view, pioneered by Lerner (1943). See also Arestis and Sawyer (2004b).

${ }^{16}$ See Hein (2014, Chapter 9) for the effects of interest rates and interest payments in post-Keynesian/Kaleckian distribution and growth models. Although, theoretically under certain conditions, higher interest rates and redistribution towards rentiers may have expansionary effects, empirically these have not been found so far. 
market persistent/hysteresis mechanisms, and because of the effects of government investment on productivity growth (Hein and Stockhammer 2010). And of course, well-functioning wage bargaining coordination applying the norm developed in the previous sub-section will support high (and increasing) levels on non-inflationary employment.

Furthermore, governments should apply progressive income taxes, relevant wealth, and property and inheritance taxes, as well as social transfers, which aim at redistribution of income and wealth in favor of low-income and low-wealth households. On the one hand, this will reduce excess saving at non-inflationary full employment and thus stabilize aggregate demand-without generating problems of unsustainable indebtedness for private households or the foreign sector. Progressive income taxation and relevant taxes on wealth, property and inheritance thus also reduce the requirements for government deficits. On the other hand, redistributive taxes and social policies will improve automatic stabilizers and thus reduce fluctuations in economic activity and the required size of short-run discretionary stabilizing fiscal policies.

Applying this approach to the euro area would require the Stability and Growth Pact and its further "developments" in the course of the crisis to be abandoned. These include the "SixPack," the Euro-Plus Pact, the Fiscal Compact, and the austerity policies imposed on the crisis countries. Each of these coordinating tools focuses on variables which governments cannot directly control (deficit-GDP ratio, debt-GDP ratio). The attempts at achieving the targets for these variables have imposed a restrictive and deflationary stance on the euro area, have prevented the recovery of the crisis countries, in particular, and have caused another euro area recession in 2012/2013 (Hein 2013, 14; Zezza 2012).

Hein (2012, Chapter 8; 2013/2014), Hein and Truger (2007) and Hein et al. (2012) have therefore suggested replacing these means of coordinating national fiscal policies with a different method, which focuses on variables governments can control and which allows coordinated fiscal policies to be implemented along the requirements for short- and long-run real stabilization at non-inflationary full employment and the roughly balanced current accounts outlined above. They have suggested the coordination of long-run expenditure paths for noncyclical government spending (i.e., those components of spending, which are under control of the government). The sum of these expenditure paths should be geared towards stabilizing aggregate demand in the euro area at non-inflationary full employment levels, and automatic stabilizers plus discretionary counter-cyclical fiscal policies could be applied to fight demand 
shocks. For each member country this would mean that, on average over the cycle and the average net tax rate in each member country given, as a first approximation, the path for noncyclical government expenditure should generate a 'structural' government deficit/surplus, balancing the "structural" private sector surplus/deficit at high levels of non-inflationary employment and a roughly balanced current account. ${ }^{17}$ This would ensure that, on average over the cycle, GDP growth is close to the BPCGR of each individual country. Cyclical deviations would be dampened by automatic stabilizers and, if required, by discretionary fiscal expansion/contraction. As shown above, the government debt-GDP ratios associated with such a strategy will not explode, and the ECB keeping nominal interest rates in each country below trend nominal GDP growth of the respective country will ensure that debt services will not have restrictive distributional effects, as shown in Appendix C. This is the reason why coordination between fiscal and monetary policies is so important for this approach. The expenditure paths for non-cyclical public sector spending of each member country should be coordinated and monitored by the European Commission, and the unwillingness to correct deviations should ultimately be sanctioned.

Following these recommendations would mean a significant contribution toward internally rebalancing the euro area and prevention of increased current account imbalances for the future. The current account surplus countries would have to apply more expansionary fiscal policies than they have, both before the crisis and since, in order to increase domestic demand growth. Together with the temporary acceptance of higher-than-euro-area average inflation rates, this would adjust their actual growth to their BPCGRs. This would also lift foreign growth for all the current account deficit countries, as well as foreign inflation, and therefore raise their BPCGRs towards their actual rates of growth, and would thus assist in allowing the current account deficit countries to reduce their deficits. Current account deficit countries have two options. They can make use of highly restrictive fiscal policies in order to adjust their actual rates of growth towards their BPCGRs - in fact, the austerity policies, which the crisis countries were particularly forced to implement as a precondition for the financial rescue measures, can be considered a version of this. Alternatively, and more favorably, current

${ }^{17}$ If the growth rate associated with a balanced current account deviates from the one associated with stable inflation employment, governments will face a short-run trade-off. However, prioritizing the achievement of the BPCGR over the growth rate associated with stable-inflation employment would generate mutual adjustment processes: rising (falling) inflation rates reducing (raising) the BPCGR, on the one hand, and endogeneity processes with respect to the stable-inflation rate of employment via labour market persistence mechanisms etc., on the other hand. 
account deficit countries, perhaps with the exception of Ireland, ${ }^{18}$ should aim at actively improving their BPCGRs. Such a policy should be actively encouraged with external assistance from the EU itself. This means, on the one hand, contributing to a reduction of the inflation differentials with respect to the surplus countries by means of unit labor cost growth below the sum of national trend productivity growth, plus the inflation target,- - as we have argued above - avoiding deflation and redistribution at the expense of the wage share and of lowincome households. On the other hand, current account deficit countries would have to increase the income elasticity of demand for their exports and to reduce the income elasticity of demand for imports by means of industrial, structural and regional policies; this means they have to improve their non-price competitiveness. We will address the related issues of this strategy, which should be the most promising in the long run, in the next section.

As already mentioned in Section 3, we would not expect perfectly balanced current accounts of euro area member countries in the medium to long run, because of necessary catching-up processes in a still-quite-heterogeneous currency area with respect to per-capita income, in particular. This means that the catching-up countries will have a persistent tendency to grow above their BPCGRs, whereas the mature countries will tend to grow below their respective BPCGRs. Coordinating fiscal policies by means of expenditure paths for non-cyclical government spending and targeting "structural" public sector deficits/surpluses should therefore take tolerable current account deficits associated with catching-up processes into account. On the one hand, this means allowing for more expansionary fiscal/less restrictive policies than described in equation (9) for high growth catching-up countries, taking into account acceptable current account deficits. On the other hand, this implies that fiscal policies in the slow-growth mature economies could be less expansionary/more restrictive than described in equation (9). As we show in Appendix B, as long as the current account deficit country, the catching-up country in the euro area, is growing sustainably faster than the mature current-account-surplus country, there is no risk of exploding net foreign debt-GDP ratios in the current-account-deficit country. Furthermore, as we also show in Appendix B, with a constant-current-account deficit-GDP ratio $\left(\Delta \mathrm{L}_{\mathrm{d}} / \mathrm{Y}_{\mathrm{d}}^{\mathrm{n}}\right)$ and constant nominal GDP growth $\left(\hat{\mathrm{Y}}_{\mathrm{d}}^{\mathrm{n}}\right)$, the net foreign liabilities-GDP-ratio

\footnotetext{
${ }^{18}$ In the case of Ireland, the current account deficit was not due to a deficit in external trade but rather a deficit in the flows of primary incomes. Ireland shows huge surpluses in the balance of goods and services which, however, fell short of the net payment commitments associated with the negative balance of primary incomes.
} 
$\left(\mathrm{L}_{\mathrm{d}} / \mathrm{Y}_{\mathrm{d}}^{\mathrm{n}}\right)$ of a current-account-deficit country will converge toward a constant value, too-i.e., the growth rates of foreign liabilities and nominal GDP will be equal $\left(\hat{\mathrm{Y}}_{\mathrm{d}}^{\mathrm{n}}=\hat{\mathrm{L}}_{\mathrm{d}}\right)$ :

$$
\hat{\mathrm{Y}}_{\mathrm{d}}^{\mathrm{n}}=\hat{\mathrm{L}}_{\mathrm{d}}=\frac{\Delta \mathrm{L}_{\mathrm{d}}}{\mathrm{L}_{\mathrm{d}}}=\frac{\frac{\Delta \mathrm{L}_{\mathrm{d}}}{\mathrm{Y}_{\mathrm{d}}^{\mathrm{n}}}}{\frac{\mathrm{L}_{\mathrm{d}}}{\mathrm{Y}_{\mathrm{d}}^{\mathrm{n}}}} \Rightarrow \frac{\mathrm{L}_{\mathrm{d}}}{\mathrm{Y}_{\mathrm{d}}^{\mathrm{n}}}=\frac{\frac{\Delta \mathrm{L}_{\mathrm{d}}}{\mathrm{Y}_{\mathrm{d}}^{\mathrm{n}}}}{\hat{\mathrm{Y}}_{\mathrm{d}}^{\mathrm{n}}} .
$$

Furthermore, the higher the (sustainable) growth trend of the catching-up economy, the higher the tolerable current account deficit-GDP ratio will be for a given maximum net foreign liabilities-GDP ratio. Finally, as we also show in Appendix B, provided that the rate of interest on net foreign debt remains below the nominal rate of growth of the economy, catching-up countries can afford a constant trade deficit-GDP ratio to be financed by capital inflows without violating a constant net foreign liabilities-GDP ratio.

Coordination of fiscal policies in the euro area would thus not have to require or target perfectly balanced current accounts and would not have to strictly follow equation (9). Sustainably higher growth in the respective current account deficit country than in the surplus countries on euro area average should therefore be the ultimate criterion for tolerable current account deficits in the coordination process of fiscal policies. The direction and use of the related net capital imports should be part of an industrial and regional development strategy aiming at facilitating catching up, as will be discussed in the next section. Current account deficits of countries with a below-surplus country average GDP growth rate, and the related current account surpluses, should not be tolerated and should be tackled symmetrically (i.e., by deficit and surplus countries, with the measures discussed above-i.e., with wage and fiscal policies in the short run and with industrial and regional policies in the long run).

As an alternative to these country-specific rules for fiscal policies in conjunction with country specific assessments of current account deficits/surpluses, Dullien (2010) and Dullien and Schwarzer (2009) have proposed a “one-size-fits-all” "External Economic Stability Pact," for the euro area countries, allowing for external deficits or surpluses of 3 percent of GDP each. For deficit countries, this would stabilize net foreign debt at 60 percent of GDP; for surplus countries the net foreign assets-GDP ratio would also become 60 percent, assuming that trend nominal GDP growth amounts to 5 percent each. In a similar vein, Horn et al. (2010) have suggested using maximum current account deficits and surpluses of 2 percent as a guideline for fiscal policy coordination in the euro area. The advantage of these suggestions over the present 
regulations is that they imply symmetric adjustment obligations for deficit and surplus countries. However, provided that a maximum net foreign debt-GDP or net foreign assets-GDP ratio is considered to be a useful target, the proposed target or threshold ratios for current account deficit- or surplus-GDP ratios would have to be differentiated for individual countries because tolerable current account deficits should be based on different growth dynamics, as can be seen in equation (11). In Appendix B we also show that with different growth dynamics, foreign liabilities-GDP ratios of current account deficit countries and foreign assets-GDP ratios of current account surplus countries cannot be stabilized simultaneously.

The alternative to coordinating member countries' national fiscal policies along the sketched guidelines would be the introduction of a relevant EU or euro area federal budget, which could assume the required real stabilization functions in order to provide high noninflationary employment in the short and in the long run for the euro area as a whole and to internally rebalance the currency union. This would mean further political integration, as demanded by Arestis and Sawyer (2013, Chapters 8-9) without spelling out any details. However, several suggestions in this area have been made recently.

The suggestions by the European Commission (2012a, 2012b) and the President of the European Council (van Rompuy et al. 2012) for an EU or euro area "fiscal capacity" builds on the enforcement of the ill-guided and currently failing policies of fiscal austerity and "structural reforms" aimed at flexibilization, liberalization and constraining workers' and trade union bargaining power. The proposed "fiscal capacity" is mainly meant to operate like an insurance system for country-specific shocks. It is financed by member state budgets, which would also be the beneficiaries in the insurance case. The European Commission (2012a) suggestion also includes the possibility for the "fiscal capacity" to borrow beyond its own resources, which is combined with a "debt redemption fund" for member country debt, as proposed by the German Council of Economic Experts (SVR 2011). Since these suggestions are deeply linked with current austerity and structural reform policies, Bibow's (2013, p. 36) conclusion that "the main purpose of the envisioned fiscal capacity appears to be that of promoting structural reform in economies in crisis" can hardly be escaped. ${ }^{19}$

\footnotetext{
${ }^{19}$ Two quotations shall suffice to support this conclusion: "Building on the Convergence and Competitiveness Instrument, the fiscal capacity for the euro area should be further enhanced. It should be autonomous and rely solely on own resources. It should provide sufficient resources to support important structural reforms in a large economy under distress." (European Commission 2012b, p. 3).
} 
A cyclical stabilization insurance fund to cope with country-specific shocks, as well as with the asymmetric effects of a single monetary policy, which are considered to be the more important ones, is also the first element of the suggestion by the Tommaso Padoa-Schioppa Group (2012, p. 5), following the credo "that the single currency requires as much fiscal federalism as necessary for its appropriate functioning, but as little as possible." This insurance fund should be created outside the EU budget, remain under direct control of national parliaments, would work in an automatic fashion and would not lead to long-term transfers in only one direction. Second, the group recommends the creation of a European Debt Agency that would provide a flexible refinancing possibility to countries in distress, in exchange for a stepwise transfer of sovereignty applying the principle "sovereignty ends when solvency ends" (Tommaso Padoa-Schioppa Group 2012, p. 7). Since countries will lose budgetary sovereignty as soon as they run into problems (or exceed the 60 percent threshold government debt-GDP ratio), the built-in incentives toward restrictive fiscal policies in times of crisis are detrimental to our requirements for the fiscal policies outlined above.

Another more promising insurance fund idea, also aimed at avoiding permanent onedirectional transfers, is the euro area unemployment insurance suggested by Dullien (2013) and Dullien and Fichtner (2013), which is included as a variant for the euro area "fiscal capacity" in van Rompuy et al. (2012), as well. Such an unemployment insurance fund could dampen the results of asymmetric shocks across member countries of the euro area and, provided that temporary deficits are accepted, it could also provide cyclical stabilization over time, even in cases of symmetric shocks. However, by design, an unemployment insurance scheme can neither provide stabilization of aggregate demand in the euro area beyond the trade cycle, nor, according to the authors, is the scheme meant to contribute to overcoming the structural imbalances in the euro area which have contributed to the crisis. And, of course, this suggestion does not tackle the institutional problem facing the euro area - the separation of fiscal authorities and the central bank, which we have highlighted above.

\footnotetext{
"Establishing a well-defined and limited fiscal capacity to improve the absorption of countryspecific economic shocks, through an insurance system set up at the central level (...) would improve the resilience of the euro area as a whole (...). A built-in incentives-based system would encourage euro area Member States eligible for participation in the shock absorption function to continue to pursue sound fiscal and structural policies in accordance with their contractual obligations. Thereby the two objectives of asymmetric shock absorption and the promotion of sound economic policies would remain intrinsically linked, complementary and mutually reinforcing." (van Rompuy et al. 2012, p. 5)
} 
In order to deal with this fundamental flaw of euro area economic policy institutions, and to provide long-run stabilization of aggregate demand for the euro area as a whole, Bibow (2013) has suggested the implementation of a euro treasury. This new institution is neither meant to mutualize public debt nor to provide permanent transfers to member countries; "instead, the euro treasury is established as a means to pool eurozone public investment spending and have it funded by proper eurozone treasury securities" (Bibow 2013, p. 1). The basic idea is to separate the public capital budget from the current budget, and have the former financed by government debt, whereas the latter should be financed by taxes, at least on average, over the trade cycle. Bibow (2013) recommends pooling the capital budget at the euro area level and have it financed by issuing euro treasury securities, and leaving current public budgets at the member country level and requiring balance over the trade cycle. Member countries would have to agree on euro-area-wide public investment expenditure, Bibow suggests three percent of GDP, and the respective growth rate for the following years; the euro treasury would issue debt accordingly and allocate the financial means to member countries in line with their (moving average) shares in euro area GDP. ${ }^{20}$ The ECB would have to guarantee the liquidity of euro treasury securities. The euro treasury would need the power to tax in order to pay interest on its debt or it would have to receive earmarked tax revenues from member countries, with taxes of member countries also being proportional to their share in euro area GDP and public investment. The euro treasury would thus have no redistributional (transfer) purposes and it would have to be separated from the EU or euro area current budget, which would have to be balanced on average over the cycle, and which could be used for transfer purposes among member countries. A member country's noncompliance with the rule of balanced current public budgets over the trade cycle would be sanctioned by means of withholding investment finance.

Bibow (2013) acknowledges that his euro treasury will not provide active countercyclical fiscal policies, but rather long-run steady investment expenditures. Counter-cyclical fiscal policies are delegated to automatic stabilizers provided by member country public budgets, and increase maneuvering room for stabilization due to declining debt servicesmember countries' current public budgets would only have to be balanced on average over the

\footnotetext{
${ }^{20}$ With long-run nominal GDP growth at 5 per cent, the public debt-GDP ratio for the euro area as a whole would stabilize at 60 per cent. And with balanced current government budgets of member countries, member country debtGDP ratios would converge towards zero.
} 
cycle: "The Euro Treasury would leave the main fiscal stabilization responsibility at the national budget level, where large in-built automatic stabilizers exist” (Bibow 2013, p. 45). One may wonder whether this is sufficient in deep recessions like 2008/2009, when government deficitGDP ratios for the (original) euro area (EA-12) exceeded six percent and reached double-digit values in single countries, and how coordination and prevention of free-riding within the euro area should be organized. However, Bibow has a solution for this, recommending an increase in deficit-financed investment expenditure in case of a severe and symmetric downturn (of, for example, more than two percent of GDP). More importantly, Bibow's euro treasury suggestion does not provide any solution to overcoming (or to preventing future) current imbalances within the euro area. For this, Bibow refers to proper nominal wage policies in member countries providing nominal unit labor cost growth and inflation in line with the euro area target rate, following the rules we have outlined above. However, as we have argued above, on the one hand this may seriously overrate the relevance of price competitiveness for persistent current account imbalances, and it may underrate the (future) requirements for capital transfers in order to improve non-price competitiveness and catching-up processes in the periphery, contributing to the re-balancing of current accounts. Therefore, only if Bibow's Euro Treasury approach is extended and developed towards full-fledged fiscal federalism, with a relevant centralized budget, the ability to issue debt and to tax in order to manage aggregate demand at the euro area level, as well as a functioning transfer system in order to deal with structural and regional imbalances and the required catching-up processes, will it be able to meet the requirements we have outlined for fiscal policies in our alternative approach. And only with these amendments and developments will this centralized approach toward fiscal policy be superior to the coordinated decentralized approach we have recommended. One may speculate which approach then requires a higher commitment to furthering political integration of the euro area.

\section{INDUSTRIAL RESTRUCTURING AND SUSTAINABLE CATCHING UP OF THE PERIPHERY}

As we have argued above, it is likely that the catching-up countries, due to their higher growth potential, will be exceeding their BPCGRs as determined in equations (1) and (2) and will run into current account deficits, which then need to be financed by capital imports - thus lifting the BPCGR in line with equations (3) and (4). In order to finance a smooth catching-up process by 
capital inflows, several prerequisites will have to be met. On the one hand, the capital inflows should be long term and stable in order to contribute to financing a catching-up process, which will not be disrupted or undermined by the instabilities of financial markets and financial flows, as witnessed during the Asian crisis in the late 1990s (Krugman 2000), the Latin American debt crisis in the early 1980s (Dodig and Herr 2014b), or the current euro crisis. However, the stabilization of capital inflows as such may not be sufficient. As became clear during the recent crisis, the sustainability of a growth process financed by capital inflows hinges largely on the type of domestic expenditure that is financed. For the future, bubble growth financed by capital imports should be prevented, capital inflows should be focused on productivity-enhancing investment and the development of export capacities, and they should be integrated into a European regional and industrial development strategy. We will briefly touch on each of these issues in what follows.

\subsection{Efficient Regulation of and Selective Interventions into Capital Flows}

First, there is a case for strict financial regulation in order to avoid unsustainable housing, constructions, and consumption booms, which have caused the recent crisis. Measures should address demand- and supply-side factors of unsustainable booms. Policies should thus aim at preventing unsustainable speculative asset price increases as well as at restricting the financial sector to lend recklessly. Access to credit for consumptive purposes should be restricted so that only sustainable debt relations are incurred. On a micro-prudential level, a range of rules could be established. For example, granting loans for consumption or real estate acquisitions should be strictly based on disposable income and not on collateral values. For real estate financing, conservative loan-to-value ratios and sufficiently high equity stakes should be applicable. Loans for speculative purposes should also be strictly limited, etc.

These micro-prudential measures need to be complemented by appropriate macroprudential tools. With the recent EU capital requirements regulations, new instruments have been introduced. The flexibility package establishes a systemic risk buffer on the national level. It can be used to address exposures in specific markets and increases the equity that needs to be held against such exposures. Additionally, higher risk weights or lower limits for certain loans are possible tools that can be employed (Detzer and Herr 2014, Chapter 6.4). On an EU level, the systemic risk board has been established, and it monitors and analyzes the buildup of systemic risk, and is able to act via the "comply or explain" mechanism (Deutsche Bundesbank 
2012). While both developments are desirable improvements, there are still severe flaws. National measures, for example, are mostly based on capital requirements. However, the effects of these on containing bubbles are not well known and may vary over time (Detzer 2012). Additionally, national regulators may be reluctant to use those tools to interrupt a prosperous boom. The systemic risk board, on the EU level, may be able to alleviate this problem, but without its own tools at hand, its capacities are limited. Therefore, further instruments at the EU or euro area level seem to be required. One possible instrument, which could be used in the euro area, is asset-based reserve requirements. Their effect is relatively easy to determine and they can drive up credit interest rates in specific markets without changing the rest of the interest rate structure. ${ }^{21}$ In addition to this, direct credit controls could be applied to keep a credit-driven bubble in check when price based measures are not sufficiently effective.

\subsection{Industrial and Regional Policy Strategy}

Second, in order to achieve a sustainable catching-up process, lifting the respective BPCGRs, the crisis countries need to develop their productive capacities, increase productivity, and improve export capacities. Following Botta (2014), such a strategy should have a strong regional character, because the conditions in the catching-up countries widely differ. ${ }^{22}$ For example, Ireland already benefits from a highly developed and dynamic manufacturing sector geared towards exports and a share of manufacturing in GDP at the same level as Germany. However, export-oriented manufacturing would have to be linked more closely with the regional base. In Spain and Portugal the share of manufacturing in GDP has been declining considerably, but it is still higher than in France or the UK. However, manufacturing lacks technological dynamism, innovations and export orientation. Greece suffers from extremely weak manufacturing, lack of technological dynamism and export orientation. ${ }^{23}$

\footnotetext{
${ }^{21}$ For an overview of asset based reserve requirements see Palley $(2004,2010)$; for their application to address asset price bubbles and their superiority to capital requirements see Detzer (2012).

${ }^{22}$ For reviews of the state of development of industry structures, productivity and trade relationships within the EU and the euro area, as well as the implications for industrial policies see the different perspectives in Aiginger (2012, 2013, 2014), Botta (2014), Pawlicki and Stobbe (2012), Pianta (2014), Reinstaller et al. (2012), Simonazzi et al. (2013) and Stöllinger et al. (2013), for example. On the general revival or return of industrial policy, see Aiginger (2014) and Wade (2012).

${ }^{23}$ According to Aiginger (2014), in 2012 the following percentage shares of manufacturing in GDP could be observed: Germany: 20, France: 8.9, UK: 8.9, Italy: 14, Ireland: 21, Spain: 12.2, Portugal: 12.2, Greece: 8.6. See Aiginger $(2013,2014)$ for a detailed study on the structure and development of manufacturing, exports capacities etc. in the periphery countries.
} 
Generally, EU industrial and regional policies should promote "high road competitiveness" based on high-quality manufacturing production as the driver of growth, instead of relying on a low-wage, labor-intensive development strategy (Aiginger 2014; Simonazzi et al. 2013). As a general rule for development, Thirlwall and Pacheco-López (2008, Chapter 5) argue that countries should try to expand their capacities in exports that are produced under increasing returns and which are highly income elastic in world markets, which means developing capacities in the production of manufactures.

A "high road" industrial policy strategy requires private and public investment in infrastructure, education, basic and applied research and development, etc., aiming at "new environmentally sustainable, knowledge intensive, high skill and high wage economic activities. Specific activities that could be targeted include: a) the protection of the environment, sustainable transportation, energy efficiency and renewable energy sources; b) the production and dissemination of knowledge, applications of ICTs and web-based activities; c) health, welfare and caring activities" (Pianta 2014, p. 3). Several proposals to revive investment in the euro area suggest improving energy efficiency and the role of renewable energies, in particular. This would have a twofold positive effect. It would not only make industries more efficient and price competitive, but also reduce the need for imports of energy resources and so reduce the income elasticity of imports. Proposals like those of the Confederation of German Trade Unions (DGB 2012) or as expressed in OFCE/IMK/ECLM (2013) aim in this direction.

Given the very different structural composition and problems of the countries of the euro area periphery, regional and industrial policy strategies for each country in question would have to be developed. These include the improvement of processes, for example increased automation, application of information technologies, and changes in the innovation cultures in the existing companies and sectors. Also the expansion to new business segments within the sectors can play an important role. For example in tourism higher segments such as business or luxury traveling could be developed (Pawlicki and Stobbe 2012). However, Simonazzi et al. (2013) argue that the southern periphery countries need to increase the diversification of their export structures. While upgrading into higher product categories in the already existing industries is an important part of this diversification process, it also includes entering new industries. As argued by Hausmann et al. (2013), the likelihood of sectors becoming competitive and successful is higher for currently underdeveloped sectors with close proximity in necessary endowments to sectors already existing and strong in a particular country. Therefore, while it 
would be desirable for each of the countries in the periphery to enter the high-tech sector, positive results in the short- to medium-term are more likely in low-tech sectors. Therefore, the overall strategy should consider those constraints.

According to Thirlwall and Pacheco-López (2008, Chapter 5), for manufacturing sectors to develop, certain forms of protection, such as selective credits, subsidies to output, as well as selective taxes on imports, may be necessary. Several of these instruments of trade protection are not available to EU and euro area member countries. However, Hausmann and Rodrik (2002) argue that trade protection or export subsidies are both just second-best solutions, since they cannot discriminate between successful innovators and unproductive imitators. Therefore, as a first-best policy, they argue for public sector credit and guarantees. ${ }^{24}$ Here government development banks, such as the KFW in Germany, which closely cooperates with the commercial banking system, could be a good example, and is in line with the rules of the single market. Additionally, the European Investment Bank (EIB) could be used and support this process in the periphery countries. In 2013 the EIB had a capital of about 58 billion euros and a total balance sheet size of about 512 billion euros (EIB 2014a). This amounts to a total of about 4 percent of EU GDP. Besides providing funds, the EIB possesses financial, and, more importantly, technical expertise and experience that it can provide to member countries (EIB 2014b). Furthermore, EU Structural Funds, which, in the period 2007-2013 reached 347 billion euros (Pianta 2014), could be used to support infant industries in catching-up countries.

\subsection{Stable Long-term Financing of Current Account Deficits Related to Successful Catching Up}

Third, successful catching up, despite lifting the BPCGR of the catching-up countries, will most likely be associated with current account deficits in these countries. This is not a principal problem, as long as growth is sustainably higher in the catching-up countries than in the mature current account surplus countries, and as long as the deficits are financed in ways that do not expose the respective countries to sudden stops or reversal of capital flows. Therefore, FDI or long-term loans should be preferred over short-term financial investments. The most obvious way to influence the types of capital flows into a country is the use of capital controls. However, their use is restricted under the current EU regulations. As a substitute, banking regulation could

\footnotetext{
24 Private investment could also be channelled into the required areas by a system of asset-based reserve requirements favouring the desired types of investment (Palley 2004), window guidance as used by the Bank of Japan for a long time (Hoshi et al. 1993) or through direct credit controls. Other incentives, like direct investment subsidies or tax breaks could also be used.
} 
incentivize banks to use more stable sources of finance. The first step in this direction has already been taken in the EU, with the new liquidity regulation ${ }^{25}$ (Detzer and Herr 2014, Chapter 15.6). A financial transaction tax may also be helpful to discourage short-term financial investments and make long-term real investments more attractive, while also generating financial resources for public investment (Schulmeister 2010).

If private capital flows to the current account deficit countries are not sufficiently stable, public funds could be used. Gros and Mayer (2013) propose the creation of a sovereign wealth fund for Germany. This fund would sell long-term bonds to German savers for retirement savings. The bonds would offer a guaranteed low and positive interest rate, plus a bonus for any surplus that is achieved. The obtained funds should then be invested according to the authors in Germany, directly, to modernize the German infrastructure. Additionally, it should provide other euro area countries with long-term capital for private companies. And, on a global level, it could be invested in a diversified portfolio and so help to depreciate the euro exchange rate. This system could be extended to all surplus countries so that a relatively large pool of patient capital is created, which can be used to provide for the necessary capital flows to the deficit countries.

Increasing and pooling a large part of public investment spending at the EU level with a focus on the catching-up countries would also decrease the need for private capital flows. Putting some investment responsibilities at the EU level is sensible, since many of the major future challenges can be more easily tackled if the solutions are jointly crafted at the EU level (e.g., climate change, development of an EU-wide transport network, etc.). Here, an EU institution would raise its own funds (member country contributions, taxes and/or debt) and then provide the necessary capital flows to the countries in question by either directly investing in the relevant projects or by providing long-term loans to the investors.

A number of different proposals include such elements. For example, the proposal of the German Trade Union Confederation (DGB 2012) includes a substantial investment package, which aims at a European turnaround in energy policy, modernization of infrastructure, improved education facilities, etc., and which amounts to 2,600 billion euros over the next ten years. To accomplish this, a European future fund is suggested, which should acquire an equity

\footnotetext{
${ }^{25}$ The new liquidity regulation, on the one hand, asks financial institutions to hold highly liquid assets as a buffer to cover sudden outflow of funds and. It also intends to ensure a more adequate matching of maturities of asset and liability positions. Both measures can contribute to make banks more resilient to sudden liquidity withdrawals (by domestic as well as international lenders).
} 
stake through a one-time wealth levy on high-wealth individuals and receive the revenues of a newly introduced financial transaction tax. It then provides long-term loans or grants to private and public investors in the EU, which facilitate the respective projects (DGB 2012). A similar idea to spur investment in Europe is brought forward by Varoufakis et al. (2013) who propose setting up a European investment program using the EIB, the European Investment Fund (EIF) ${ }^{26}$ and a newly funded venture capital fund. Since they want these institutions to act on a much larger scale than previously done, they argue that the ECB should keep the interest rate of the bonds issued by the EIB and the EIF at a low level by intervening in the secondary market if necessary. Also Bibow's (2013) proposal to pool investment spending with a new Euro Treasury could make sense in this context. While we do not see his suggestion as a proper solution for the fiscal policy requirements in the euro area, as explained above, the idea of pooling the public investment at the euro area level and funding them by issuing euro treasury bonds, would be a good idea for two main reasons: On the one hand, single countries would be sheltered from sudden capital flow reversals and, on the other hand, it would ensure that government budgets would not be consolidated at the expense of necessary investment spending.

\section{CONCLUSIONS}

In this paper we have outlined alternative policy recommendations addressing the problems of differential inflation, divergence in competitiveness, and associated current account imbalances within the euro area. We have argued that the major purpose of these alternative policy proposals should be to generate sustainably high demand and output growth in the euro area as a whole, providing high levels of non-inflationary employment, as well as preventing "export-led mercantilist" and "debt-led consumption boom" types of development, both within the euro area and with respect to the role of the euro area in the world economy. We have provided a basic framework in order to systematically address the related issues, making use of Thirlwall's $(1979 ; 2002)$ model of a BPCGR. Based on this framework, we have outlined the required stance for alternative economic policies and have discussed the implications for alternative

\footnotetext{
${ }^{26}$ The EIF was founded in 1994 and is part of the EIB group. It focuses on the provision of risk finance for small and medium sized companies across Europe (EIF 2014).
} 
monetary, wage/incomes and fiscal policies in the euro area as a whole, as well as the consequences for structural and regional policies, particularly in the euro area periphery.

We have argued that monetary policies of the ECB should refrain from fine-tuning output and inflation but should target low real interest rates, focus on financial stability and should convincingly act as lender of last resort, both for the banking system and for the euro area member country governments. For the latter, we have suggested that the ECB should target country-specific caps on government bond yields given by the long-run nominal GDP growth rate of the respective country. Wage policies should aim at stabilizing income shares and contribute to stable inflation rates at the target rate for the euro area as a whole. Wage policies should also contribute to rebalancing price competitiveness within the euro area, but we would not expect large effects on the prevailing current account imbalances. Therefore, the major burden for internally rebalancing the euro area, as well as for stabilizing aggregate demand at non-inflationary full employment levels, falls on fiscal policies. We have suggested that functional finance fiscal policies should be applied, and we have encouraged the utilization of long-run government deficits/surpluses in order to take up the excess of private saving over private investment at non-inflationary full employment output levels in each country, thus also preventing current account surpluses and deficits. In order to implement such a policy, we have proposed the coordination of expenditure paths for non-cyclical government spending of member countries as a strategy, accepting the present political preferences, which seem to exclude a United States of Europe with a federal government budget for the near future.

Finally, we have argued that perfectly balanced current accounts within the euro area should not be expected as long as the periphery is catching up with respect to the center. Successful catching up will be associated with current account deficits in the periphery and current account surpluses in the center. These should be accepted and taken into account when coordinating fiscal policies, provided that the periphery grows at a sustainably higher rate than the center. For this purpose, industrial restructuring and catching up should prevent unsustainable credit-driven bubbles and consumption booms, improve existing industries, and develop new export industries in order to lift the BPCGR of the periphery countries.

Furthermore, the prevailing and remaining current account deficits require stable capital inflows, for which we have provided several suggestions. 


\section{References}

Aiginger, K. (2012): "A Systemic Industrial Policy to Pave a New Growth Path for Europe," WIFO Working Papers, No. 421, Vienna: WIFO.

(2013): “A New Strategy for the European Periphery,” WIFO Working Papers, No. 443, Vienna: WIFO.

(2014): "Industrial Policy for a Sustainable Growth Path," WIFO Working Papers, No. 469, Vienna: WIFO.

Arestis, P. (2009): "New Consensus Macroeconomics and Keynesian Critique," in: Hein, E., Niechoj, T., Stockhammer, E. (eds.), Macroeconomic Policies on Shaky Foundations. Whither Mainstream Economics?, Marburg: Metropolis.

(2011): "European Economic and Monetary Union Policies from a Keynesian Perspective," in: Hein, E., Stockhammer, E. (eds.), A Modern Guide to Keynesian Macroeconomics and Economic Policies, Cheltenham: Edward Elgar.

(2013): "Economic Theory and Policy: A Coherent Post-Keynesian Approach," European Journal of Economics and Economic Policies: Intervention, 10 (2): 243-255.

Arestis, P., Sawyer, M. (2004a): "Re-examining Monetary and Fiscal Policy for the $21^{\text {st }}$ Century," Cheltenham: Edward Elgar.

(2004b): “On Fiscal Policy and Budget Deficits,” Intervention. Journal of Economics, 1 (2): 61-74.

(2011): "The Design Faults of the Economic and Monetary Union," Journal of Contemporary European Studies, 19 (1): 21-32.

(2013): “Economic and Monetary Union Macroeconomic Policies. Current Practices and Alternatives," Basingstoke: Palgrave Macmillan.

Arghyrou, M.G., Chortareas, G. (2008): "Current Account Imbalances and Real Exchange Rates in the Euro area," Review of International Economics, 16: 747-765.

Bibow, J. (2013): “Lost at Sea: the Euro Needs a Euro Treasury,” Working Paper No. 780, Annandale-on-Hudson: Levy Economics Institute of Bard College.

Botta, A. (2014): "Structural Asymmetries at the Roots of the Eurozone Crisis: What's New for Industrial Policy in the EU?," PSL Quarterly Review, 67 (269): 169-216.

Brunnermeier, M. et al. (2011), European safe bonds: ESBies, http://euro-nomics.com/wpcontent/uploads/2011/09/ESBiesWEBsept262011.pdf.

Carasco, C., Peinado, P. (2014): "On the Origins of European Imbalances in the Context of the European Integration,” FESSUD Working Paper Series, University of Leeds, forthcoming. 
Clarida, R., Gali, J., Gertler, M. (1999): "The Science of Monetary Policy: a New Keynesian Perspective," Journal of Economic Literature, 37: 1661-1707.

De Grauwe, P. (2011a): “The Governance of a Fragile Eurozone," CEPS Working Document, No. 346, Brussels: Centre for European Policy Studies.

(2011b): "The European Central Bank: Lender of Last Resort in the Government Bond Markets?," CESIFO Working Paper, No. 3569, Munich: CESIFO.

(2013): "Design Failures in the Eurozone - Can They be Fixed?," LSE "Europe in Question” Discussion Paper Series, LEQS Paper No. 57/2013, London School of Economics and Political Science, and European Economy, Economic Papers, No. 491/2013, Brussels: European Commission.

De Grauwe, P., Moesen, W. (2009): “Gains for All: A Proposal for a Common Eurobond," Intereconomics, May/June, 132-135.

Delpla, J., von Weizsäcker, J. (2010): “The Blue Bond Proposal,” Bruegel Policy Brief, 2010/3, Brussels: Bruegel.

Detzer, D. (2012): "New Instruments for Banking Regulation and Monetary Policy After the Crisis," Intervention: European Journal of Economics and Economic Policies, 9 (2): 233-254.

Detzer, D., Herr, H. (2014): "Financial Regulation in Germany," FESSUD Working Paper Series, No. 55/2014, University of Leeds.

Deutsche Bundesbank (2012): Monthly Report April 2012, Frankfurt am Main: Deutsche Bundesbank.

DGB (Confederation of German Trade Unions) (2012): “A Marshall Plan for Europe,” Proposal by the DGB for an economic stimulus, investment and development programme for Europe, Berlin: DGB.

Dodig, N., Herr, H. (2014a): "Policies to Reduce Current Account Imbalances in the EMU," FESSUD Working Paper Series, University of Leeds, forthcoming.

(2014b): "Previous Financial Crises Leading to Stagnation - Selected Case Studies," Berlin School of Economics and Law, Institute for International Political Economy (IPE) Working Paper, No. 33/2014, and FESSUD Working Paper Series, No. 24, University of Leeds.

Domar, E.D. (1944): "The 'burden of the debt' and National Income," American Economic Review, 34: 794-828.

Draghi, M. (2012): Speech by Mario Draghi, President of the European Central Bank at the Global Investment Conference in London, 26 July 2012, http://www.ecb.europa.eu/press/key/date/2012/html/sp120726.en.html. Accessed September 18, 2014. 
Dullien, S. (2010): “Towards a Sustainable Growth Model for Europe: Institutional Framework," Internationale Politik und Gesellschaft, 1/2010: 36-44.

(2013): "A Euro-area Wide Unemployment Insurance as an Automatic Stabilizer: Who Benefits and Who Pays?," Paper prepared for the European Commission (DG EMPL).

Dullien, S., Fichtner, F. (2013): “A Common Unemployment Insurance System for the Euro Area," DIW Economic Bulletin, 3(1): 9-14.

Dullien, S., Schwarzer, D. (2009): “The Euro Zone Needs an External Stability Pact," SWP Comments 2009/C09, Berlin: German Institute for International and Security Affairs.

ECB (2012): "Technical Features of Outright Monetary Transactions," press release, http://www.ecb.europa.eu/press/pr/date/2012/html/pr120906_1.en.html. Accessed September 18, 2014.

EIB (2014a): European Investment Bank Financial Report 2013, Luxembourg: EIB.

EIB (2014b): Produkte: Finanzieren, Mittel kombinieren und beraten, http://www.eib.org/products/index.htm. Accessed September 18, 2014.

EIF (2014): European Investment Fund, http://www.eif.org/index.htm. Accessed September 18, 2014.

ETUC (2012): "Solidarity in the Crisis and Beyond: Towards a Coordinated European Trade Union Approach to Tackling Social Dumping," Discussion Note to the ETUC Winter School, Copenhagen, 7-8 February, 2012, http://www.etuc.org/IMG/pdf/ETUC_Winter_School_-_Discussion_note_FINAL.pdf. Accessed September 18, 2014.

ETUI (2014): Benchmarking Working Europe, Brussels: ETUI.

European Commission (2010): "Surveillance of Intra-euro-area Competitiveness and Imbalances," European Economy, Vol. 1/2010, Brussels: European Commission, Directorate-General for Economic and Financial Affairs.

(2011), "Green Paper on the Feasibility of Introducing Stability Bonds," Brussels, $\operatorname{COM}(2011) 818$ final, 23 November 2011, http://ec.europa.eu/europe2020/pdf/green_paper_en.pdf. Accessed September 18, 2014. (2012a): "A Blueprint for a Deep and Genuine Economic and Monetary Union: Launching a European Debate," Brussels, 30 November 2012, COM(2012) 777 final/2, http://ec.europa.eu/commission_20102014/president/news/archives/2012/11/pdf/blueprint_en.pdf. Accessed September 18, 2014.

(2012b): "A Blueprint for a Deep and Genuine EMU: Launching a European Debate," Executive summary, Brussels, 28 November 2012, http://ec.europa.eu/commission_2010- 
2014/president/news/archives/2012/11/pdf/blueprint_exec_en.pdf. Accessed September $18,2014$.

(2014): AMECO database, May 2014, http://ec.europa.eu/economy_finance/db_indicators/ameco/index_en.htm. Accessed September 18, 2014.

Goodfriend, M., King, R.G., (1997): "The New Neoclassical Synthesis and the Role of Monetary Policy," in Bernanke, B.S., Rotemberg, J.J. (eds.), NBER Macroeconomics Annual: 1997, Cambridge, MA: MIT Press.

Gros, D., Mayer, T. (2013): "Ein Vermögensbildungsfonds für Deutschland, "Frankfurter Allgemeine Zeitung, 22 November 2013, http://www.faz.net/aktuell/wirtschaft/wirtschaftspolitik/gastbeitrag-einvermoegensbildungsfonds-fuer-deutschland-12674947.html. Accessed September 18, 2014.

Hausmann, R., Hidalgo, C.A., Bustos, S., Coscia, M., Simoes, A., Yildirim, M.A. (2013): "The Atlas of Economic Complexity: Mapping Paths to Prosperity," Cambridge, MA: MIT Press.

Hausmann, R., Rodrik, D. (2002): "Economic Development as Self-discovery,” National Bureau of Economic Research Working Paper 8952.

Hein, E. (2002): "Monetary Policy and Wage Bargaining in the EMU: Restrictive ECB Policies, High Unemployment, Nominal WageR and Inflation Above the Target," Banca Nazionale del Lavoro Quarterly Review, 55: 299-337.

(2012): "The Macroeconomics of Finance-dominated Capitalism - and its Crisis," Cheltenham: Edward Elgar.

(2013): "Finance-dominated capitalism, Re-distribution and the Financial and Economic Crises: a European Perspective," in: Dejuan, O., Febrero, E., Uxo, J. (eds.), PostKeynesian Views of the Crisis and its Remedies, Abingdon: Routledge.

(2013/14): "The Crisis of Finance-dominated Capitalism in the Euro Area, Deficiencies in the Economic Policy Architecture and Deflationary Stagnation Policies," Journal of Post Keynesian Economics, 36 (2): 325-354.

(2014): "Distribution and Growth after Keynes: A Post-Keynesian Guide," Cheltenham: Edward Elgar, forthcoming.

Hein, E., Dodig, N. (2014): "Financialisation, Distribution, Growth and Crises - Long-run Tendencies," Berlin School of Economics and Law, Institute for International Political Economy (IPE) Working Paper, No. 35/2014, and FESSUD Working Paper Series No. 23, 2014, University of Leeds.

Hein, E., Niechoj, T., Schulten, T., Truger, A. (eds.) (2005): "Macroeconomic Policy Coordination in Europe and the Role of the Trade Unions," Brussels: ETUI. 
Hein, E., Stockhammer, E. (2010): "Macroeconomic Policy Mix, Employment and Inflation in a Post-Keynesian Alternative to the New Consensus Model," Review of Political Economy, 22: 317-354.

(2011): “A Post-Keynesian Macroeconomic Model of ilflation, Distribution and Employment," in: Hein, E., Stockhammer, E. (eds.), A Modern Guide to Keynesian Macroeconomics and Economic Policies, Cheltenham: Edward Elgar.

Hein, E., Truger, A. (2005): "Macroeconomic Coordination as an Economic Policy Concept Opportunities and Obstacles in the EMU," in Hein, E., Niechoj, T., Schulten, T., Truger, A. (eds.), Macroeconomic Policy Coordination in Europe and the Role of the Trade Unions, Brussels: ETUI.

(2007): "Fiscal Policy and Macroeconomic Performance in the Euro Area: Lessons for the Future," in: Bibow, J., Terzi, A. (eds.), Euroland and the World Economy. Global Player or Global Drag?, Basingstoke: Palgrave Macmillan.

(2011): "Finance-dominated Capitalism in Crisis - the Case for a Keynesian New Deal at the European and the Global Level," in Arestis, P., Sawyer, M. (eds.), New Economics as Mainstream Economics, Basingstoke: Palgrave Macmillan.

(2014a): "Fiscal Policy and Rebalancing in the Euro Area: A Critique of the German Debt Brake from a Post-Keynesian Perspective," Panoeconomicus, 61 (1): 21-38.

(2014b): "Future Fiscal and Debt Policies: Germany in the Context of the European Monetary Union," in: Arestis, P., Sawyer, M. (eds.), Fiscal and Debt Policies for the Future, Basingstoke: Palgrave Macmillan.

Hein, E., Truger, A., van Treeck, T. (2012): "The European Financial and Economic Crisis: Alternative Solutions from a (Post-)Keynesian Perspective,” in: Arestis, P., Sawyer, M. (eds.), The Euro Crisis, Basingstoke: Palgrave Macmillan.

Horn, G.A., Niechoj, T., Tober, S., van Treeck, T., Truger, A. (2010), "Reforming the European Stability and Growth Pact: Public Debt is Not the Only Factor, Private Debt Counts as Well,” IMK Report, No. 51, July, Düsseldorf: Macroeconomic Policy Institute (IMK) at Hans Böckler Foundation.

Hoshi, T., Scharfstein D.S., Singleton K.J. (1993): "Japanese Corporate Investment and Bank of Japan Guidance of Commercial Bank Lending," in: K. Singleton (ed.), Japanese Monetary Policy, Chicago: University of Chicago Press.

Kollmann, R. Ratto, M., Roeger, W., in't Veld, J., Vogel, L. (2014): “What Drives the German Current Account? And How Does it Affect Other EU Member States?," European Economy, Economic Papers, No. 516, Brussels: European Commission, DirectorateGeneral for Economic and Financial Affairs.

Krugman, P.R. (ed.) (2000): "Currency Crises. A National Bureau of Economic Research Conference Report," Chicago: University of Chicago Press. 
Lerner, A. (1943): "Functional Finance and the Federal Debt," Social Research, 10: 38-51.

McCombie, J. (2002): "Balance-of-payments-constrained Economic Growth,” in: King, J.E. (ed.), The Elgar Companion to Post Keynesian Economics, Cheltenham: Edward Elgar.

Meyer, L.H. (2001): “Inflation Targets and Inflation Targeting," Federal Reserve Bank of St. Louis Quarterly Review, November/December: 1-14.

OFCE, IMK, ECLM (2013): Independent Annual Growth Survey 2014, http://www.iagsproject.org/ressources.htm. Accessed September 18, 2014.

Palley, T. (2004): "Asset-based Reserve Requirements: Reasserting Domestic Monetary Control in an Era of Financial Innovation and Instability," Review of Political Economy, 16: 4358.

(2010): “Asset Price Bubbles and Counter-cyclical Monetary Policy: Why Central Banks have been Wrong and What Should be Done," Intervention. European Journal of Economics and Economic Policies, 7 (1): 91-108.

(2011): "Monetary Union Stability: The Need for a Government Banker and the Case for a European Public Finance Authority,” IMK Working Paper 2/2011, Düsseldorf: Macroeconomic Policy Institute (IMK) at Hans Boeckler Foundation.

Pawlicki, P., Stobbe, A. (2012): “Greece, Ireland, Portugal: More Growth via Innovation,” EU Monitor European Integration, Frankfurt: DB Research.

Pianta, M. (2014): “An Industrial Policy for Europe,” WP-EMS - Working Papers Series in Economics, Mathematics and Statistics, 2014/01, Universita degli Studi di Urbino "Carlo Bo," Facolta di Economia.

Reinstaller, A., Hölz. W., Kutsam, J., and Schmid, C. (2012): "The Development of Productive Structures of EU Member States and their International Competitiveness," Vienna: WIFO.

Rochon, L.-P., Setterfield, M. (2007): "Interest Rates, Income Distribution and Monetary Policy Dominance: Post-Keynesians and the 'fair rate' of Interest," Journal of Post Keynesian Economics, 30: 13-42.

Schröder, E. (2011): "Trade Balances in Germany and the United States: Demand Dominates Price," paper presented at the $15^{\text {th }}$ conference of the Research Network Macroeconomics and Macroeconomic Policies (FMM), "From Crisis to Growth? The Challenge of Imbalances, Debt, and Limited Resources,” Berlin, 27 - 29 October 2011.

Schulmeister, S. (2010): "Mitten in der großen Krise. Ein New Deal für Europa," Wien: Picus.

Schulten, T. (2002): “A European Solidaristic Wage Policy?,” European Journal of Industrial Relations, 8: 173-196. 
(2005): "Foundations and Perspectives of Trade Union Wage Policy in Europe," in: Hein, E., Niechoj, T., Schulten, T., Truger. A. (eds.), Macroeconomic Policy Coordination in Europe and the Role of the Trade Unions, Brussels: ETUI.

(2012): "European Minimum Wage Policy: A Concept for Wage-led Growth and Fair Wages in Europe," International Journal of Labour Research, 4 (1): 85-104.

Schulten, T., Müller, T. (2013): “A new European Interventionism? The Impact of the New European Economic Governance on Wages and Collective Bargaining," in: Natali, D., Vanhercke, B. (eds.), Social Developments in the EU 2012. Brussels: European Trade Union Institute and the European Social Observatory.

Simonazzi, A., Ginzburg, A., Nocella, G. (2013): "Economic Relations Between Germany and Southern Europe," Cambridge Journal of Economics, 37: 653-675.

Stockhammer, E., Onaran, Ö. (2012): "Rethinking Wage Policy in the Face of the Euro Crisis. Implications of the Wage-led Demand Regime," International Review of Applied Economics, 26 (2): 191-203.

Stöllinger, R. et al. (2013): "A 'Manufacturing Imperative' in the EU - Europe's Position in Global Manufacturing and the Role of Industrial Policy,” WIIW Research Reports 391, Vienna: WIIW.

Storm, S., Naastepad, C.W.M. (2014): "Crisis and Recovery in the German Economy: The Real Lessons," Working Group on the Political Economy of Distribution Working Paper No. 2, New York: Institute for New Economic Thinking.

SVR (2011): “Verantwortung für Europa Übernehmen.” Jahresgutachten 2011/12, Wiesbaden: Statistisches Bundesamt.

Thirlwall, A.P. (1979): "The Balance of Payments Constraint as an Explanation of International Growth Differences," Banca Nazionale del Lavoro Quarterly Review, 128: 45-53. (2002): "The Nature of Economic Growth," Cheltenham: Edward Elgar.

Thirlwall. A.P., Pacheco-López, P. (2008): "Trade Liberalisation and the Poverty of Nations," Cheltenham: Edward Elgar.

Tommaso Padoa-Schioppa Group (2012): "Completing the Euro: A Road Map Towards Fiscal Union in Europe," Notre Europe, 26 June 2012, http://www.notreeurope.eu/media/completingtheeuroreportpadoa-schioppagroupnejune2012.pdf?pdf=ok. Accessed September 18, 2014.

Van Rompuy, H. et al. (2012): “Towards a Genuine Economic and Monetary Union," Report by the President of the European Council, in collaboration with the Presidents of the Commission, the Eurogroup and the ECB, 5 May 2012, http://www.consilium.europa.eu/uedocs/cms_Data/docs/pressdata/en/ec/134069.pdf. Accessed September 18, 2014. 
Varoufakis, Y., Holland, S., Galbraith J.K. (2013): “A Modest Proposal for Resolving the Eurozone Crisis," version 4.0, available at: http://varoufakis.files.wordpress.com/2013/07/a-modest-proposal-for-resolving-theeurozone-crisis-version-4-0-final1.pdf. Accessed September 18, 2014.

Wade, R.H. (2012): "Return of Industrial Policy?," International Review of Applied Economics, 26 (2): 223-239.

Zezza, G. (2012): "The Impact of Fiscal Austerity in the Eurozone," Review of Keynesian Economics, Inaugural Issue: 37-54. 


\section{APPENDIX A: BALANCE OF PAYMENTS CONSTRAINED GROWTH RATE (BPCGR) IN A CURRENCY UNION-WITH AND WITHOUT PERMANENT AND SUSTAINABLE NET CAPITAL INFLOWS}

Following Thirlwall (2002, chapter 5), we can derive the BPCGR in the following way. We start with a current account equilibrium:

$$
\mathrm{p}_{\mathrm{d}} \mathrm{X}=\mathrm{p}_{\mathrm{f}} \mathrm{eM}
$$

where $\mathrm{p}_{\mathrm{d}}$ is domestic prices, $\mathrm{p}_{\mathrm{f}}$ is foreign prices in foreign currency, e is the exchange rate, $\mathrm{X}$ is exports, and $\mathrm{M}$ is imports. We are ignoring primary incomes coming from and going abroad, as well as income transfers. Equation (1) in growth rates gives:

$$
\hat{\mathrm{p}}_{\mathrm{d}}+\hat{\mathrm{X}}=\hat{\mathrm{p}}_{\mathrm{f}}+\hat{\mathrm{e}}+\hat{\mathrm{M}} \text {. }
$$

Exports are determined in the following way:

$$
\mathrm{X}=\mathrm{Q}\left(\frac{\mathrm{p}_{\mathrm{d}}}{\mathrm{p}_{\mathrm{f}} \mathrm{e}}\right)^{\eta} \mathrm{Y}_{\mathrm{f}}^{\varepsilon}, \quad \eta<0, \varepsilon>0,
$$

with $\eta$ denoting price elasticity of demand for exports, $\varepsilon$ income elasticity of demand for exports, and $\mathrm{Y}_{\mathrm{f}}$ foreign real income. From equation (A3) we get for the growth rate of exports:

$$
\hat{\mathrm{X}}=\eta\left(\hat{\mathrm{p}}_{\mathrm{d}}-\hat{\mathrm{p}}_{\mathrm{f}}-\hat{\mathrm{e}}\right)+\varepsilon \hat{\mathrm{Y}}_{\mathrm{f}}
$$

Imports are given as:

$$
\mathrm{M}=\mathrm{R}\left(\frac{\mathrm{p}_{\mathrm{f}} \mathrm{e}}{\mathrm{p}_{\mathrm{d}}}\right)^{\psi} \mathrm{Y}_{\mathrm{d}}^{\pi}, \quad \psi<0, \pi>0,
$$

with $\psi$ denoting price elasticity of demand for imports, $\pi$ income elasticity of demand for imports, and $\mathrm{Y}_{\mathrm{d}}$ domestic real income. From equation (A5) we get for the growth rate of imports:

$$
\hat{\mathrm{M}}=\psi\left(\hat{\mathrm{p}}_{\mathrm{f}}+\hat{\mathrm{e}}-\hat{\mathrm{p}}_{\mathrm{d}}\right)+\pi \hat{\mathrm{Y}}_{\mathrm{d}}
$$

Substituting equations (A6) and (A4) into equation (A2) yields the domestic rate of growth which is consistent with a current account equilibrium, the BPCGR:

$$
\hat{\mathrm{Y}}_{\mathrm{d}}^{\mathrm{b}}=\frac{(1+\eta+\psi)\left(\hat{\mathrm{p}}_{\mathrm{d}}-\hat{\mathrm{p}}_{\mathrm{f}}-\hat{\mathrm{e}}\right)+\varepsilon \hat{\mathrm{Y}}_{\mathrm{f}}}{\pi} .
$$

Since in a currency union the nominal exchange rate among member countries is fixed, they all use the same currency, and the BPCGR for the individual member country becomes:

$$
\hat{\mathrm{Y}}_{\mathrm{d}}^{\mathrm{b}}=\frac{(1+\eta+\psi)\left(\hat{\mathrm{p}}_{\mathrm{d}}-\hat{\mathrm{p}}_{\mathrm{f}}\right)+\varepsilon \hat{\mathrm{Y}}_{\mathrm{f}}}{\pi} .
$$


Including net capital inflows (C) measured in domestic currency in order to finance persistent current account deficits, equation (A1) becomes an identity:

$$
\mathrm{p}_{\mathrm{d}} \mathrm{X}+\mathrm{C}=\mathrm{p}_{\mathrm{f}} \mathrm{eM} \text {. }
$$

Writing equation (A9) in growth rates

$$
\left(\hat{\mathrm{p}}_{\mathrm{d}}+\hat{\mathrm{X}}\right) \theta+\hat{\mathrm{C}}(1-\theta)=\hat{\mathrm{p}}_{\mathrm{f}}+\hat{\mathrm{e}}+\hat{\mathrm{M}}
$$

with $\theta$ as the share of export revenues in total receipts to pay for imports and (1- $\theta)$ as the share or net capital inflows. Using equations (A4) and (A6) again, the BPCGR from equation (A7) is modified to:

$$
\hat{\mathrm{Y}}_{\mathrm{d}}^{\mathrm{b}}=\frac{(1+\theta \eta+\psi)\left(\hat{\mathrm{p}}_{\mathrm{d}}-\hat{\mathrm{p}}_{\mathrm{f}}-\hat{\mathrm{e}}\right)+\theta \varepsilon \hat{\mathrm{Y}}_{\mathrm{f}}+(1-\theta)\left(\hat{\mathrm{C}}-\hat{\mathrm{p}}_{\mathrm{d}}\right)}{\pi},
$$

and equation (A8) turns to:

$$
\hat{\mathrm{Y}}_{\mathrm{d}}^{\mathrm{b}}=\frac{(1+\theta \eta+\psi)\left(\hat{\mathrm{p}}_{\mathrm{d}}-\hat{\mathrm{p}}_{\mathrm{f}}\right)+\theta \varepsilon \hat{\mathrm{Y}}_{\mathrm{f}}+(1-\theta)\left(\hat{\mathrm{C}}-\hat{\mathrm{p}}_{\mathrm{d}}\right)}{\pi} .
$$

Net capital inflows lift the BPCGR if the growth rate of these inflows in real terms - taking into account domestic inflation - exceeds the growth rate of foreign GDP multiplied by the income elasticity of exports. 


\section{APPENDIX B: CURRENT ACCOUNT IMBALANCES AND NET FOREIGN ASSETS/LIABILITIES}

In a two-country model net foreign liabilities of the domestic economy $\left(\mathrm{L}_{\mathrm{d}}\right)$ are equal to net foreign assets of the foreign economy $\left(\mathrm{A}_{\mathrm{f}}\right)$ :

$$
L_{d}=A_{f} \text {. }
$$

Current account deficits (surpluses) mean a change in net foreign liabilities (assets) and hence:

$$
\Delta \mathrm{L}_{\mathrm{d}}=\Delta \mathrm{A}_{\mathrm{f}}
$$

Dividing equation (B2) by equation (B1), it follows that the growth rate of net foreign liabilities of the domestic economy has to be equal to the growth rate of net foreign assets of the foreign economy:

$$
\hat{\mathrm{L}}_{\mathrm{d}}=\frac{\Delta \mathrm{L}_{\mathrm{d}}}{\mathrm{L}_{\mathrm{d}}}=\hat{\mathrm{A}}_{\mathrm{f}}=\frac{\Delta \mathrm{A}_{\mathrm{f}}}{\mathrm{A}_{\mathrm{f}}} .
$$

A constant net foreign liabilities-GDP ratio, or a constant net foreign-assets-GDP ratio, requires that net foreign liabilities, or net foreign assets, and nominal GDP

$\left(\mathrm{p}_{\mathrm{d}} \mathrm{Y}_{\mathrm{d}}=\mathrm{Y}_{\mathrm{d}}^{\mathrm{n}} ; \mathrm{p}_{\mathrm{f}} \mathrm{Y}_{\mathrm{f}}=\mathrm{Y}_{\mathrm{f}}^{\mathrm{n}}\right)$ of the respective economy grow at the same rate:

$$
\frac{L_{d}}{Y_{d}^{n}} \text { constant, if } \hat{L}_{d}=\hat{Y}_{d}^{n}
$$

$$
\frac{A_{f}}{Y_{f}^{n}} \text { constant, if } \hat{A}_{f}=\hat{Y}_{f}^{n} \text {. }
$$

Taking into account equation (B3) this means that the constancy of both the net foreign liabilities-GDP ratio of the domestic economy and the net foreign assets-GDP ratio of the foreign economy requires that the two economies have to grow at the same rate:

$$
\frac{L_{d}}{Y_{d}^{n}} \text { and } \frac{A_{f}}{Y_{f}^{n}} \text { constant, if } \hat{L}_{d}=\hat{Y}_{d}^{n}=\hat{A}_{f}=\hat{Y}_{f}^{n}
$$

By definition in a two-country model, net foreign liabilities have to grow at the same rate as net foreign assets. GDP growth rates of the domestic economy and the foreign economy, however, will not necessarily be equal. If this is the case, only one country can see a constant net foreign liabilities-/net foreign assets-GDP ratio, whereas the other will witness continuously falling or rising net foreign liabilities-/net foreign assets-GDP ratios. If we assume that the current account deficit country (the domestic economy) grows at a higher rate than the current account surplus country (the foreign economy), $\hat{Y}_{d}^{n}>\hat{Y}_{f}^{n}$, either a constant foreign liabilities-GDP ratio of the 
domestic economy will be accompanied by a rising foreign assets-GDP ratio of the foreign economy; or a constant foreign assets-GDP ratio of the foreign economy will be accompanied by a falling foreign liabilities-GDP ratio of the domestic economy. Of course, one may also obtain both a falling foreign liabilities-GDP ratio of the domestic economy and a rising foreignassets-GDP ratio of the foreign economy. There may hence only be a tendency towards an everrising foreign debt-GDP ratio of the domestic economy, if the current account deficit country (the domestic country), grows at a lower rate than the current account surplus country (the foreign country), $\hat{\mathrm{Y}}_{\mathrm{d}}^{\mathrm{n}}<\hat{\mathrm{Y}}_{\mathrm{f}}^{\mathrm{n}}$.

From equations (B3), and (B4.a) and (B4.b) we obtain that the long-run constant net foreign liabilities-GDP ratio for the domestic country and the net long-run constant net foreign assets-GDP ratio of the foreign economy are given as:

$$
\begin{aligned}
& \hat{\mathrm{Y}}_{\mathrm{d}}^{\mathrm{n}}=\hat{\mathrm{L}}_{\mathrm{d}}=\frac{\Delta \mathrm{L}_{\mathrm{d}}}{\mathrm{L}_{\mathrm{d}}}=\frac{\frac{\Delta \mathrm{L}_{\mathrm{d}}}{\mathrm{Y}_{\mathrm{d}}^{\mathrm{n}}}}{\frac{\mathrm{L}_{\mathrm{d}}}{\mathrm{Y}_{\mathrm{d}}^{\mathrm{n}}}} \Rightarrow \frac{\mathrm{L}_{\mathrm{d}}}{\mathrm{Y}_{\mathrm{d}}^{\mathrm{n}}}=\frac{\frac{\Delta \mathrm{L}_{\mathrm{d}}}{\mathrm{Y}_{\mathrm{n}}^{\mathrm{n}}}}{\hat{\mathrm{Y}}_{\mathrm{d}}^{\mathrm{n}}}, \\
& \hat{\mathrm{Y}}_{\mathrm{f}}^{\mathrm{n}}=\hat{\mathrm{A}}_{\mathrm{f}}=\frac{\Delta \mathrm{A}_{\mathrm{f}}}{\mathrm{A}_{\mathrm{f}}}=\frac{\frac{\Delta \mathrm{A}_{\mathrm{f}}}{\mathrm{Y}_{\mathrm{f}}^{\mathrm{n}}}}{\frac{\mathrm{A}_{\mathrm{f}}}{\mathrm{Y}_{\mathrm{f}}^{\mathrm{n}}}} \Rightarrow \frac{\mathrm{A}_{\mathrm{f}}}{\mathrm{Y}_{\mathrm{f}}^{\mathrm{n}}}=\frac{\frac{\Delta \mathrm{A}_{\mathrm{f}}}{\hat{Y}_{\mathrm{f}}^{\mathrm{n}}}}{} .
\end{aligned}
$$

With constant current account deficit-GDP ratios, or current account surplus-GDP ratios, and constant nominal GDP growth rates, the net foreign liabilities-GDP ratio, or the net foreign assets-GDP ratio, will each converge toward a definite value. As should be clear from the arguments put forward above, this can only hold for both economies simultaneously if their GDP growth rates are the same.

Let us assume next that the current account deficit (surplus) is composed of a trade deficit (surplus) and net interest payments (revenues) on the stock of net foreign liabilities (assets):

$$
\Delta \mathrm{L}_{\mathrm{d}}=-\mathrm{NX}_{\mathrm{d}}+\mathrm{iL}_{\mathrm{d}}=\Delta \mathrm{A}_{\mathrm{f}}=\mathrm{NX}_{\mathrm{f}}+\mathrm{iA} \mathrm{f}_{\mathrm{f}}
$$

with $\mathrm{NX}_{\mathrm{d}}=\mathrm{p}_{\mathrm{d}} \mathrm{X}_{\mathrm{d}}-\mathrm{p}_{\mathrm{f}} \mathrm{e} \mathrm{M}_{\mathrm{d}}$ as net exports of the domestic economy and $\mathrm{NX} \mathrm{f}_{\mathrm{f}}=\mathrm{p}_{\mathrm{f}} \mathrm{eX} \mathrm{X}_{\mathrm{f}}-\mathrm{p}_{\mathrm{d}} \mathrm{M}_{\mathrm{f}}$ as net exports of the foreign economy, $i$ as the rate of interest on the stock of debt/assets, $p_{d}$ as domestic price, $\mathrm{p}_{\mathrm{f}}$ as foreign price and e as the exchange rate. Of course, in our two-country model with the domestic economy as current account deficit economy, we have: 
$-\mathrm{NX}_{\mathrm{d}}=\mathrm{NX}_{\mathrm{f}}$. Inserting equation (B7) into equations (B6.a) and (B6.b) yields:

(B8.a)

$$
\frac{L_{d}}{Y_{d}^{n}}=\frac{\frac{-N X_{d}+i L_{d}}{Y_{d}^{n}}}{\hat{Y}_{d}^{n}}=\frac{\frac{-N X_{d}}{Y_{d}^{n}}}{\hat{Y}_{d}^{n}-i},
$$

$$
\frac{A_{f}}{Y_{f}^{n}}=\frac{\frac{N X_{f}+i A_{f}}{Y_{f}^{n}}}{\hat{Y}_{f}^{n}}=\frac{\frac{N X_{f}}{Y_{f}^{n}}}{\hat{Y}_{f}^{n}-i} .
$$

Therefore, provided that the rate of interest remains below the nominal rate of growth of the domestic economy, a constant trade deficit-GDP ratio to be financed by capital inflows will lead to a constant net foreign liabilities-GDP ratio. However, as soon as the rate of interest exceeds domestic nominal GDP growth, a positive net export-GDP ratio is required in order to stabilize the net foreign liabilities-GDP ratio. 


\section{APPENDIX C: GOVERNMENT DEFICIT, GOVERNMENT DEBT AND NOMINAL GDP}

A constant government debt-GDP ratio $\left(\mathrm{B} / \mathrm{Y}^{\mathrm{n}}\right)$ requires that government debt $(\mathrm{B})$ and nominal $\operatorname{GDP}\left(\mathrm{Y}^{\mathrm{n}}\right)$ grow at the same rate:

$$
\hat{\mathrm{B}}=\frac{\Delta \mathrm{B}}{\mathrm{B}}=\hat{\mathrm{Y}}^{\mathrm{n}}=\frac{\Delta \mathrm{Y}^{\mathrm{n}}}{\mathrm{Y}^{\mathrm{n}}} .
$$

Since the government deficit (D) is given by:

$$
\mathrm{D}=\mathrm{G}-\mathrm{T}=\Delta \mathrm{B}
$$

with $\mathrm{G}$ representing government expenditures and $\mathrm{T}$ government revenues (taxes etc.), equation (C1) becomes:

$$
\hat{B}=\frac{\Delta B}{B}=\frac{D}{B}=\frac{\frac{D}{Y^{n}}}{\frac{B}{Y^{n}}}=\hat{Y}^{n} \quad \Rightarrow \quad \frac{B}{Y^{n}}=\frac{\frac{D}{Y^{n}}}{\hat{Y}^{n}} .
$$

With a constant government deficit-GDP ratio and a constant nominal rate of growth of the economy, the government debt-GDP ratio will thus converge toward a definite value.

Let us now decompose the government deficit into a primary deficit (D') and the net interest payments on the stock of government debt (iB):

$$
\mathrm{D}=\mathrm{D}^{\prime}+\mathrm{iB} \text {. }
$$

Inserting this into equation $(\mathrm{C} 3)$ yields:

$$
\frac{B}{Y^{n}}=\frac{\frac{D^{\prime}+i B}{Y^{n}}}{\hat{Y}^{n}}=\frac{\frac{D^{\prime}}{Y^{n}}+i \frac{B}{Y^{n}}}{\hat{Y}^{n}} .
$$

With a balanced primary budget, $\mathrm{D}^{\prime}=0$ and hence $\mathrm{D}=\mathrm{iB}$, governments can thus service their debt by their current government deficits, hence without devoting tax revenues to debt services and hence without distributing income from the general public to the rentiers holding government debt, and stabilize the government debt-GDP ratio-provided that nominal GDP growth is positive. Rearranging equation (C5) gives:

$$
\frac{B}{Y^{n}}=\frac{\frac{D^{\prime}}{Y^{n}}}{\hat{Y}^{n}-i} .
$$

If the growth rate of nominal GDP exceeds the nominal interest rate on government debt, governments can also run a primary deficit without compromising a long-run stable government debt-GDP ratio. However, if nominal GDP growth falls short of the nominal rate of interest, 
stabilizing the government debt-GDP ratio will require a primary surplus in the government budget - and thus implies the use of tax revenues in order to satisfy the income demands of the rentiers holding government debt. 